\title{
PETROLEUM CONSUMPTION AND ECONOMIC GROWTH RELATIONSHIP: EVIDENCE FROM THE INDIAN STATES
}

\author{
Seema Narayan, Thai-Ha Le, Badri Narayan Rath and Nadia Doytch*
}

This paper reveals that over the period 1985-2013, the wealthier states of India experienced a prevalence of the feedback hypothesis between real gross domestic product growth and petroleum consumption in the short run and the long run. Over the short term, the whole (major) 23 Indian state panels show support for the conservative hypothesis. Regarding the panels comprising low- and middle-income Indian states, although there appeared to be significant bidirectional effects in the long run, none of the results suggest that energy consumption increases economic growth. This implies that growth in energy demand can be controlled without harming economic growth. The results, however, indicate that for the low- and middle-income states, increases in petroleum consumption could adversely affect economic activity in the short and long run. These findings relate to the aggregate data on petroleum. Examining the short-run and long-run energy-growth linkages using disaggregated data on petroleum consumption reveals that only a few types of petroleum products have stable long-run relationships with economic growth. In fact, with disaggregated petroleum data, the vector error correction model (VECM) and cointegration results support the neutral hypothesis for high-incomes states. For the low- and middle-income groups, while the conservation effect is found to prevail in the short run and the long run, higher economic growth appears to reduce consumption of selected types of petroleum products.

JEL classification: 013, Q43, C33

Keywords: petroleum consumption, economic growth, feasible generalized least squares (FGLS), cross-sectional dependence, Indian states

Seema Narayan, RMIT University, Australia. Thai-Ha Le, corresponding author, RMIT University, Viet Nam (email: ha.lethai@rmit.edu.vn). Badri Narayan Rath, Indian Institute of Technology Hyderabad, India. Nadia Doytch, City University of New York, Brooklyn College and Graduate Center. 


\section{INTRODUCTION}

Energy is an inseparable component of economic development. Among the different energy sources, such as coal, oil, natural gas, electricity, solar, wind and nuclear energy, oil continues to play a vital role in a country's economy, supporting, for example, transportation, industries, and households. In this regard, India is no exception, however, oil is the largest energy source of the country, accounting for 31 per cent of primary energy consumption. In 2018, oil consumption in India was 239.1 million tons oil equivalent, an increase of 5.3 per cent compared to the previous year, and represented a 5.1 per cent share of total world oil consumption (British Petroleum, 2019, p. 21). In terms of barrels per day, the country consumed $5,156,000$ barrels per day (bpd), increased by 5.9 per cent compared to the previous year, and accounted for 5.2 per cent of world oil consumption in 2018, according to British Petroleum (2019). India was the third largest consumer of crude oil in the world during the year, only behind the United States of America $(20,456,000$ million bpd) and China $(13,525,000$ million bpd) in terms of consumption (British Petroleum, 2019).

According to Reuters, in 2017, India became the third largest net oil importer in the world, with imports averaging 4.37 million barrels per day (Verma, 2018). Because of its fast growing economy, energy demand in India rose rapidly over the years, in terms of per capita energy consumption and oil consumption. This is attributable to the increased affordability of oil (on the back of the drop in the price of oil) for a large section of its population who previously could not afford it, as is evident in the motorization of the Indian economy (Sen and Sen, 2016).

In per capita terms, however, oil consumption in India remains relatively low in comparison to the world's largest consuming economies and to other non-Organization for Economic Cooperation and Development (OECD) countries (Sen and Sen, 2016). Interestingly, even though the population of India is 1.3 billion, the country still lags other emerging market powerhouses in oil consumption per capita, giving it room for rapid growth. In September 2014, a policy initiative, the "Make in India" programme, was launched by Prime Minister Narendra Modi. ${ }^{1}$ The objective of the programme is to put manufacturing at the heart of the country's growth model. A government target of increasing the manufacturing sector's share of gross domestic product (GDP) from approximately 15 per cent to 25 per cent by the beginning of the next decade can be expected to equate to a significant increase in demand for energy, and higher oil consumption in manufacturing (Sen and Sen, 2016). Also of note, a programme involving infrastructure construction (roads and national highways), which is being partly funded through revenue from higher taxation of oil and oil products, is likely to support oil demand growth in the country.

For more information on "Make in India" scheme, see www.makeinindia.com/about. 
Against this background, for this paper, we use state-wise petroleum consumption and economic growth data for 23 Indian states. Our study relates to the voluminous literature that examines the role of the energy consumption $(E)$ and economic growth $(Y)$ nexus in the cases of a single country and multiple countries (Akarca and Long, 1980; Asafu-Adjaye, 2000; Fang and Le, forthcoming; Kraft and Kraft, 1978; Le, 2016; Le and Nguyen, 2019; Le and Quah, 2018; Lee and Chang, 2005; Apergis and Payne, 2009a; 2019b; Narayan, Narayan and Popp, 2010a; 2010b; Narayan, 2016; Oh and Lee, 2004; Proops, 1984; Rafiq and Salim, 2009; Stern, 1993; and Yang, 2000). The E-Y nexus is governed by four hypotheses: the growth hypothesis; the conservation hypothesis; the feedback hypothesis; and the neutrality hypothesis. ${ }^{2}$

A number of recent studies have analysed the relationship of oil consumption and economic growth in India. The E-Y literature on India has been based on gas (Akhmat and Zaman, 2013); oil (Akhmat and Zaman, 2013); nuclear energy (Akhmat and Zaman, 2013; Wolde-Rufael, 2010); coal (Govindaraju and Tang, 2013); electricity (Abbas and Choudhury, 2013; Akhmat and Zaman, 2013; Cowan and others, 2014; Ghosh, 2002; Nain, Ahmad and Kamaiah, 2015) and aggregate energy consumption (Pao and Tsai, 2010; Vidyarthi, 2013; Yang and Zhao, 2014) (table 1).

As indicated earlier, we examine the state data for 23 states as a panel and also divide the states by income in order to account for some heterogeneity that arises as a result of income (see section II). As explained by the International Energy Agency (IEA) $(2015$, p. 21), "( $(t)$ he widespread differences between regions and states within India necessitate looking beyond national figures because of the country's size and heterogeneity, in terms of demographics, income levels and resource endowments, and also because of a federal structure that leaves many important responsibilities for energy with individual states." While our study is predominantly based on aggregate data, we also check the robustness of our findings using disaggregated petroleum data ${ }^{3}$ and have found the disaggregated data to be informative and useful because of the importance of each petroleum product tends to vary across states.

Foreshadowing our key results, in the long run, we find evidence in favour of the feedback effect for the all states panel in addition to all the subpanels of states at different income levels. In the short run, we find that while the all states panel shows support for the conservative hypothesis, all income panels seem to show the presence of the feedback effect. Regarding the signs of the effects, however, we find that while petroleum consumption and economic growth are positively related for the high-income

The growth hypothesis indicates that $E$ causes $Y$; the conservation hypothesis indicates that $Y$ causes $E$; the feedback hypothesis treats both $E$ and $Y$ as leading each other; and the neutrality hypothesis relates no linkage between $E$ and $Y$.

We are thankful to an anonymous reviewer for the suggestion of introducing disaggregated data in the study. 
states in the short run and the long run, they can be negatively linked for the middleand low-income states. The use of disaggregated petroleum products data in the analysis reveals that cointegration between petroleum products and income is missing for the high-income states and only present for selected petroleum products in the case of low- and middle-income states.

The remainder of the study is organized as follows. Section II includes a review of the related literature with a focus on India. Section III contains an explanation of the aggregate petroleum consumption and economic growth patterns for 23 Indian states. In section IV, the econometric methods and models used to examine the four hypotheses associated with the petroleum consumption-economic growth nexus are presented. Section $\mathrm{V}$ includes a discussion of the key findings relating to the aggregate data on petroleum consumption, while section VI presents the results derived using the disaggregated data on petroleum consumption. Section VII provides a discussion on the key findings and their implications relating to aggregate and disaggregated data on petroleum consumption. Section VIII concludes the study with policy implications.

\section{LITERATURE REVIEW}

A handful of studies have investigated the link between energy consumption and economic growth in India (Paul and Bhattacharya, 2004; Vidyarthi, 2013; Tiwari, Shahbaz and Hye, 2013; Shahbaz and others, 2016; Nain, Bharatam and Kamaiah, 2017). Paul and Bhattacharya (2004) find the prevalence of the feedback hypothesis for the Indian economy over the period 1950-1996, when energy consumption leads to economic growth in the short run and economic growth leads to higher energy consumption in the long run. Vidyarthi (2013) shows evidence of the feedback effect for electricity consumption, although the casual effects in the short run and the long run were different from Paul and Bhattacharya (2004) (see table 1). Nasreen and Anwar (2014) find that the feedback effect is prevalent in the short run and long run over the period 1983-2011. Tiwari, Shahbaz and Hye (2013) examine the Environmental Kuznets Curve (EKC) hypothesis of India using aggregate coal consumption and economic growth data along with carbon dioxide (CO2) emissions. They find feedback hypothesis between economic growth and $\mathrm{CO} 2$ emissions. The same interpretation is drawn between coal consumption and $\mathrm{CO} 2$ emissions.

Abbas and Choudhury (2013) concur when looking at electricity consumption in India and agricultural GDP over the period 1972-2008. Some authors find evidence of a unidirectional relationship relating to the growth hypothesis, which suggests that energy consumption drives economic growth in the long run (Pao and Tsai, 2010) and in the short run (Yang and Zhao, 2014; Nain, Ahmad and Kamaiah, 2015). Akhmat and Zaman (2013) suggest a unilateral link for electricity and gas consumption in India in the long run. Wolde-Rufael (2010) shows the same linkage for nuclear energy in the 
long run. Other studies on India show evidence of the conservative hypothesis, or a unidirectional link flowing from economic growth to energy consumption, for different sources of energy: electricity consumption (Ghosh, 2002 (in the short run); Abbas and Choudhury, 2013 (in the short run and the long run)); nuclear energy in the long run (Akhmat and Zaman, 2013); and coal consumption in India in the short run (Govindaraju and Tang, 2013). Similarly, Shahbaz and others (2016) examine the relationship between globalization and energy consumption in India and have found acceleration of globalization results in a decline in energy consumption, but economic growth increases energy demand in the long run.

In the literature, we find that there is also evidence in favour of the neutrality hypothesis for India. Akhmat and Zaman (2013), for instance, find a relationship between fuel and oil consumption and economic growth over the period 1975-2009. Similarly, Govindaraju and Tang (2013) find evidence supporting the neutrality hypothesis in the case of coal in the long run for the period 1965-2009; and Cowan and others (2014) find this for electricity consumption over the period 1990-2010.

Almost all these studies come up with short-term and long-term inferences from Granger causality tests drawing on the vector autoregressive (VAR) model or the vector error correction model (VECM), depending on whether a cointegration relationship between non-stationary variables, $\mathrm{E}$ and $\mathrm{Y}$, is established. The key variations are in the datasets in terms of panel or time series (aggregate or disaggregated), and sample periods; and the techniques (cointegration and causality tests) (see table 1). Naser (2015) finds that a long-run impact of oil is associated with nuclear energy consumption on economic growth in India, along with China, the Republic of Korea and the Russian Federation. Bildirici and Bakirtas (2014) argue that for China and India, this relationship is bidirectional.

Regarding the cointegration tests, several studies have used the time series Engle-Granger univariate cointegration approach (see, for instance, Paul and Bhattacharya, 2004); others have used the time series Johansen multivariate cointegration method (Paul and Bhattacharya, 2004). Furthermore, to address the issue of a small sample, some authors use the autoregressive distributed lag (ARDL) bounds test (such as Nain, Bharatam and Kamaiah, 2017); others have tackled the small sample problem by including more countries in the study. This gives them the benefit of taking advantage of a larger dataset and using panel-based cointegration methods, such as the Pedroni $(1999 ; 2004)$ cointegration test, the Kao (1999) test, or the Johansen/ Fisher test, to derive results from a larger dataset (Nasreen and Anwar, 2014; Pao and Tsai, 2010). Instead of applying the standard Granger causality test, Kónya (2006) employs the bootstrap panel causality approach to allow for cross-section dependence and heterogeneity within the panel. Yang and Zhao (2014), in place of the usual in-sample Granger causality tests, apply an out-of-sample Granger causality test to better gauge the out-of-sample forecasting performance of models. Wolde-Rufael (2010) 


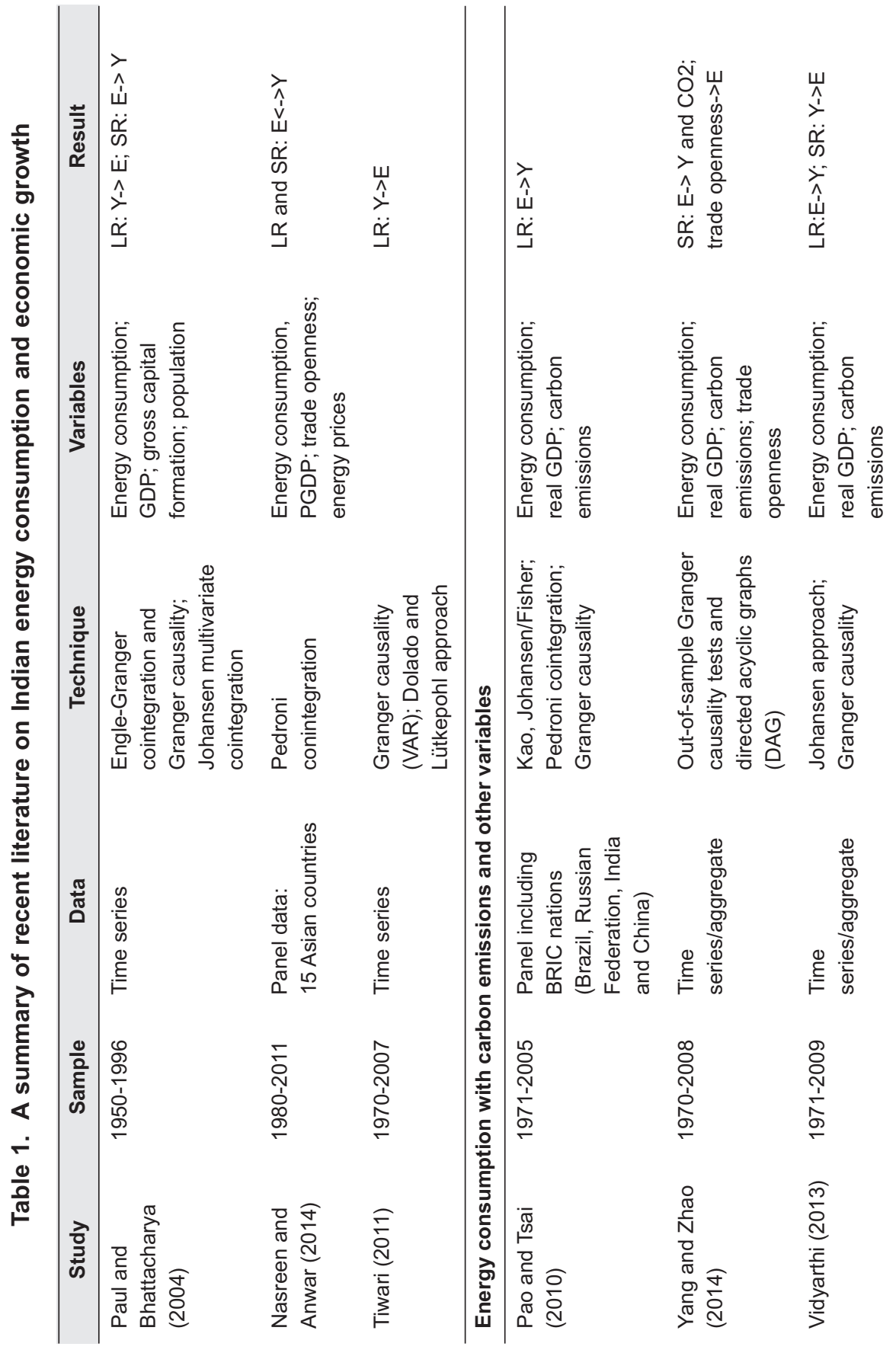




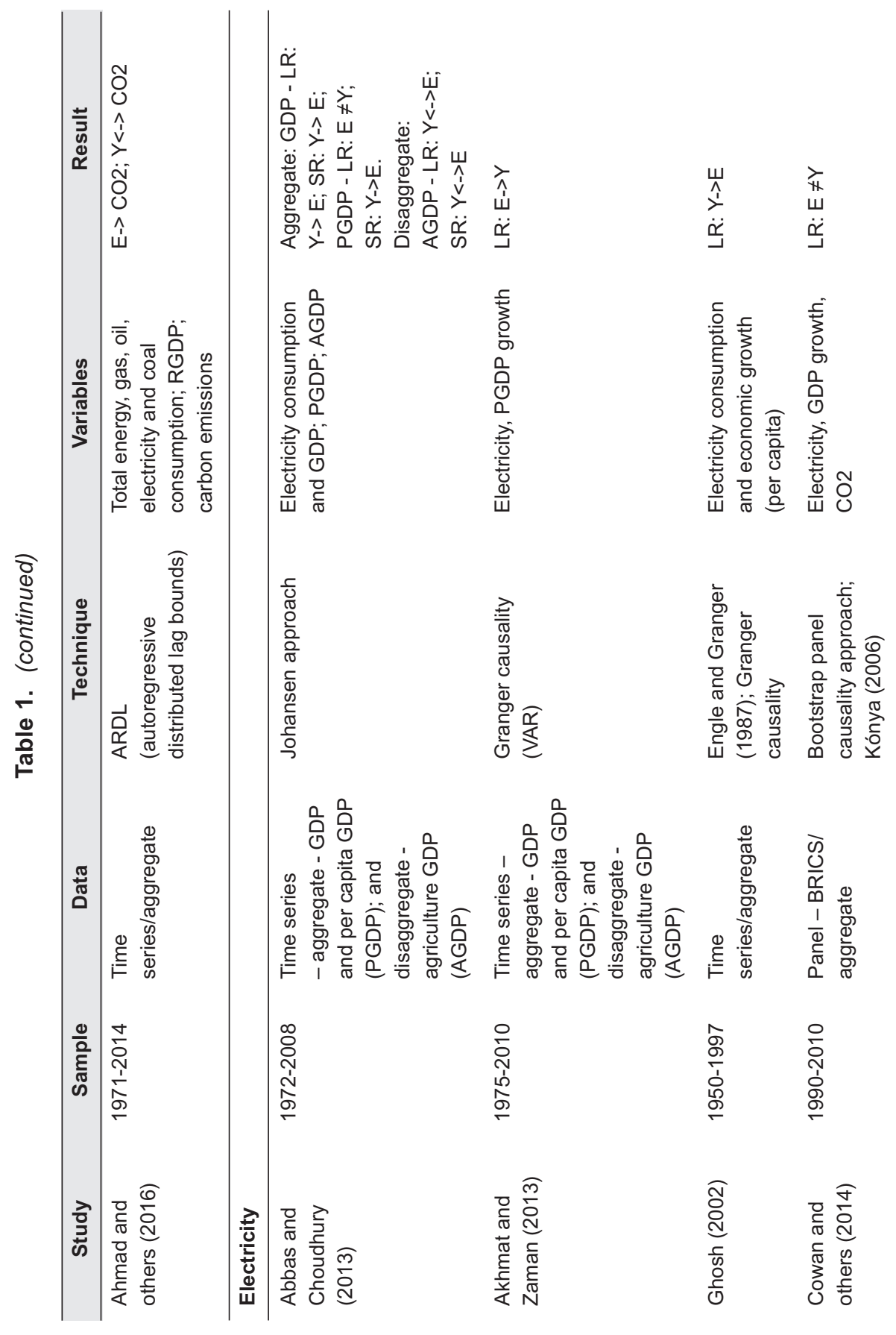




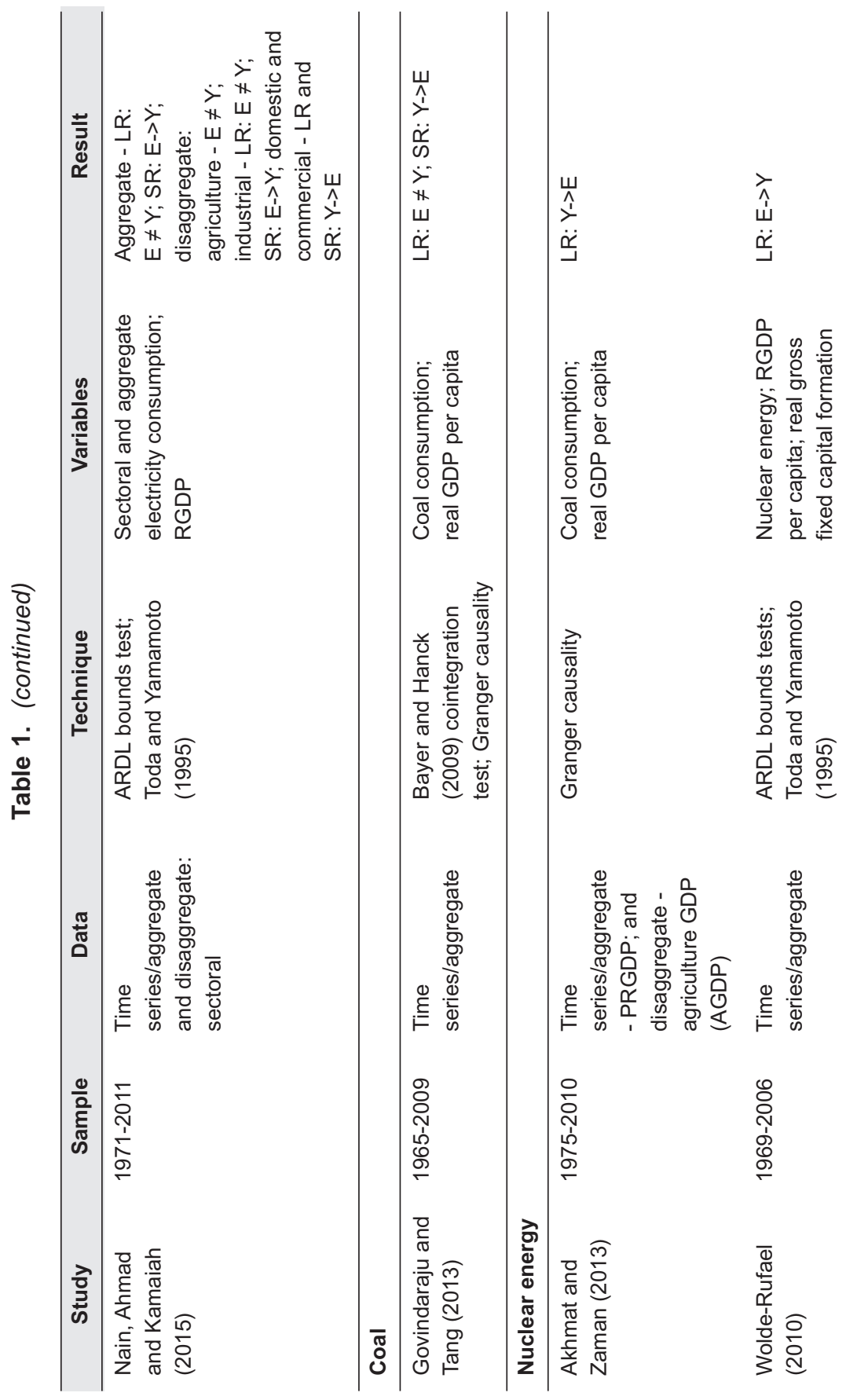




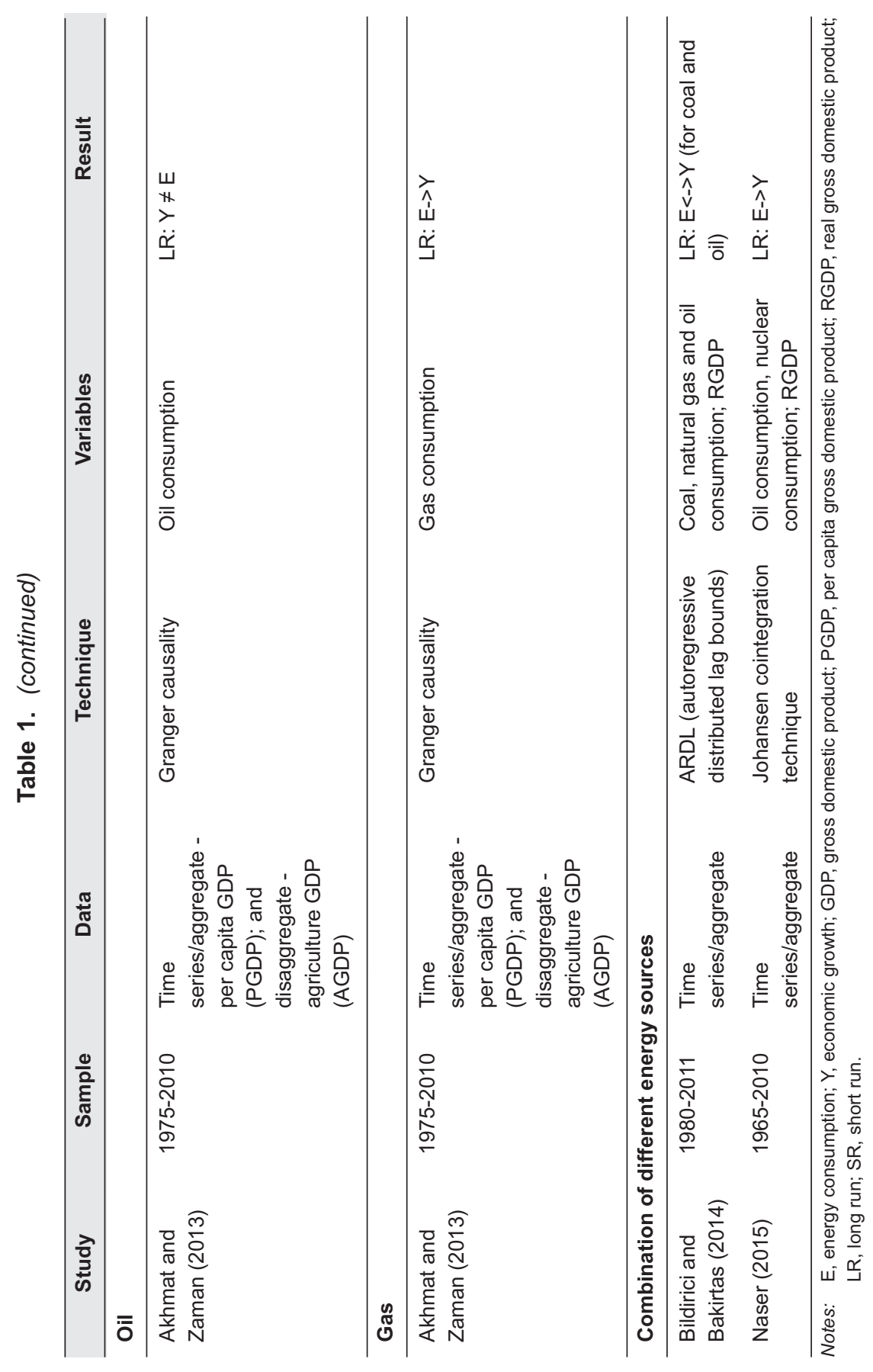


apply the multivariate Toda and Yamamoto (1995) approach, which is often employed in the case of a small sample.

A sectoral perspective on the manufacturing sector of India suggests that the three dominant and highly energy-intensive manufacturing industries are steel, aluminium and cement. Dutta and Mukherjee (2010) suggest that unless these sectors innovate in the way they are using energy, India will lose global competitiveness in related industries.

Innovation in the energy sector of India is also necessary because of the impact of oil and gas energy consumption on CO2 emissions. Ahmad and others (2016) find that energy consumption from oil and gas, electricity and coal consumption contributes to carbon emissions in India. The question of energy consumption in the country as a determinant of growth is inevitably intertwined with the issue of raising $\mathrm{CO} 2$ emissions. A series of papers that examine various scenarios for future energy consumption indicate that none of the traditional sources of energy, oil, gas, coal, hydrocarbon, nuclear, hydrogen, hydro and renewables, will be sufficient to meet the future energy demands and that India would have to rely on imports for a significant portion of its energy supply (Parikh and others, 2009; Parikh and Parikh, 2011). At the same time, the most feasible scenario for $\mathrm{CO} 2$ emissions reduction is to cut energy demand and boost energy efficiency in production and consumption. That would make it possible to meet environmental conservation goals without compromising on economic development and future growth (Parikh and Parikh, 2011).

While the overall energy consumption of the country is estimated to rise sharply in the next decade, energy inequalities in the country are rampant. Saxena and Bhattacharya (2018) examine the role of caste, tribe, and religion as determinants of energy inequality in India. Using data at the household level for 2011-2012, the authors estimate the energy inequalities stemming from differential access to liquid petroleum gas and electricity, focusing on disadvantaged groups, such as castes, tribes, and religious denominations, and find that these factors are relevant to energy access. Even though the above-mentioned social inequalities in energy access exist, residential energy consumption in India is expected to quadruple in the next decade because of lifestyle changes related to the county's recent economic growth (Bhattacharyya, 2015). Urbanization, a fast-growing middle class and western-style consumerism are factors behind the expected overbearing residential energy consumption expansion in the near future. A large part of the energy supply burden on liquefied petroleum gas is expected to fall (Bhattacharyya, 2015). This makes the unveiling of the link between petroleum consumption and economic growth in the context of India even more pressing.

The expected rapid growth in energy consumption, in conjunction with the above described energy inequalities and contribution to carbon emissions, make India a prime candidate for the development of renewable energy technologies (Singh, 2018). In addition to coping with the energy deficits, transitioning to renewables would reduce the exposure of India to variations in the price of crude oil. A recent study by Mallick, 
Mahalik and Sahoo (2018) finds that crude oil price reduces significantly private investment, whereas economic growth and globalization tend to boost it. Economic growth and urbanization are the key factors pushing energy demand higher in the long run, Shahbaz and others (2016) argue that transitioning to renewables would allow for supporting raising energy demand without the negative side effects on pollution and of energy access inequality in India.

\section{DATA}

Our study covers 23 Indian states, ${ }^{4}$ which in total encompasses approximately 95 per cent of the national area. We collected the petroleum consumption and its by-products consumption data for the states from the States of India database, a comprehensive compilation of state-level statistics published by the Centre for Monitoring Indian Economy. The only problem with this is related to the state-wise population data for each year spanning from 1985/86 to 2013/14. The petroleum product-wise data referred to in each state over the sample period are available in the absolute value (in thousand tonnes). Therefore, in order to convert the data to per capita term, we have collected state-wise population data from the Economic and Political Weekly Research Foundation database for the same period and then divided the aggregate petroleum consumption and the various by-products by the population for each state. Furthermore, we note that this is an unbalanced panel data, as there are missing observations for a number of states. All of the per capita variables (petroleum products and the by-products consumption) that we converted are in kilograms. For the by-products of the petroleum data not available for some states for different years, the per capita term becomes zero for those observations.

State-wise income per capita is defined as real per capita net state domestic product at factor cost data, with a base year of 2004/05 and is sourced from the Reserve Bank of India. ${ }^{5}$ We divided these 23 states into three panels based on their level of income. For this classification, we calculated the average per capita income of each state over the study period 1985-2013 and categorized the states by high, middle, and low income, presented in table $2 .^{6}$

4 Andhra Pradesh, Arunachal Pradesh, Assam, Bihar, Delhi, Gujarat, Haryana, Himachal Pradesh, Jammu and Kashmir, Karnataka, Kerala, Madhya Pradesh, Maharashtra, Manipur, Meghalaya, Nagaland, Odisha, Punjab, Rajasthan, Tamil Nadu, Tripura, Uttar Pradesh, and West Bengal.

5 Real gross domestic product (RGDP) data are extracted from Indiastat. Available at Indiastat.com.

6 Our classification of the Indian states by income closely follows Narayan, Rath and Narayan (2012) for at least 15 states. 
Table 2. Panels by income

\begin{tabular}{llll}
\hline \multicolumn{1}{c}{ High-income states } & Middle-income states & \multicolumn{1}{c}{ Low-income states } \\
\hline States & Delhi, Gujarat, Haryana, & Andhra Pradesh, & Assam, Bihar, \\
& Maharashtra, Punjab, & Arunachal Pradesh, & Madhya Pradesh, \\
& Tamil Nadu & Himachal Pradesh, & Manipur, Meghalaya, \\
& Jammu and Kashmir, & Odisha, Rajasthan, \\
& Karnataka, Kerala, & Uttar Pradesh, \\
& Nagaland, Tripura, & \\
& West Bengal & \\
&
\end{tabular}

The preliminary observations indicate a strong positive correlation between income and energy consumption, at least in the average data in per capita terms. In table 3 , we display the average per capita income and per capita energy consumption. Note that for the high-income states, which are also the most industrially developed ones (Delhi, Gujarat, Haryana, Maharashtra, Punjab, and Tamil Nadu) the average per capita income is 36,997 Indian rupee (Rs) (US\$537) and their average petroleum consumption stands at $173 \mathrm{~kg}$ of oil equivalent per capita, which is also the highest. The middle-income states (Andhra Pradesh, Arunachal Pradesh, Himachal Pradesh, Jammu and Kashmir, Karnataka, Kerala, Nagaland, Tripura, and West Bengal) have an average per capita income of Rs24,451 and petroleum consumption is the second largest on average at $71.2 \mathrm{~kg}$ of oil equivalent per capita. The low-income states (Assam, Bihar, Madhya Pradesh, Manipur, Meghalaya, Odisha, Rajasthan, and Uttar Pradesh) on average show a per capita income of Rs15,281 and consume the least amount of petroleum

Table 3. Descriptive statistics

\begin{tabular}{|c|c|c|c|c|c|c|c|c|}
\hline & \multicolumn{2}{|c|}{ All states } & \multicolumn{2}{|c|}{ High-income states } & \multicolumn{2}{|c|}{ Middle-income states } & \multicolumn{2}{|c|}{ Low-income states } \\
\hline & PEC & PRGDP & PEC & PRGDP & PEC & PRGDP & PEC & PRGDP \\
\hline Mean & 92.4 & 24534.1 & 173.1 & 36996.8 & 71.2 & 24450.8 & 55.7 & 15280.8 \\
\hline Median & 70.7 & 20711.0 & 159.6 & 30808.2 & 62.3 & 22376.9 & 48.8 & 14333.0 \\
\hline Maximum & 399.3 & 118411.0 & 399.3 & 118411.0 & 189.5 & 58961.0 & 159.3 & 37154.0 \\
\hline Minimum & 18.8 & 2728.0 & 72.8 & 12736.7 & 18.8 & 8275.4 & 24.4 & 2728.0 \\
\hline Std. dev. & 63.6 & 15109.5 & 63.0 & 19815.8 & 33.1 & 10456.4 & 26.1 & 6170.1 \\
\hline Skewness & 1.5 & 2.1 & 0.9 & 1.6 & 0.8 & 0.9 & 1.9 & 0.5 \\
\hline Kurtosis & 5.5 & 10.3 & 3.8 & 6.2 & 3.3 & 3.3 & 7.0 & 3.9 \\
\hline Jarque-Bera & $437.5^{*}$ & $1984.9^{*}$ & $29.2^{*}$ & $150.0^{*}$ & $30.9^{*}$ & $35.4^{*}$ & $295.8^{*}$ & $17.8^{*}$ \\
\hline Observations & 667 & 667 & 174 & 174 & 261 & 261 & 232 & 232 \\
\hline
\end{tabular}

Notes: *Normality is rejected at the 1 per cent level. The mean values of the per capita real GDP (PRGDP) are in Indian rupees while petroleum is measured in terms kg per capita; PEC, per capita energy consumption. 
(56 $\mathrm{kg}$ of oil equivalent per capita) in comparison to the other two income groups (see figure 1).

In the figure, we display energy consumption and real gross domestic product (RGDP) in per capita terms. For the high-income states (with the exception of Delhi), per capita RGDP is closely tracked by petroleum consumption per capita and thus this relationship seems to be positive. We find a similar pattern for middle- and low-income panels, with the exception of a few states. For instance, for the middle-income states, including Arunachal Pradesh, Nagaland, Kerala, and West Bengal, and more recently Jammu and Kashmir, the plots show a decline in petroleum consumption amid steady growth in income per capita. Of the low-income states, for Bihar, an agriculture-based state and the third largest in terms of population, a significant decline in petroleum consumption per capita in the 2000s is shown even though per capita income has been increasing steadily. For other low-income states, including Assam, Madhya Pradesh, Manipur, and Uttar Pradesh, similar relationships are shown on a year-to-year basis, although the long-term trend is upward. 
Figure 1. Per capita energy consumption and real gross domestic product by state

\section{High-income states}
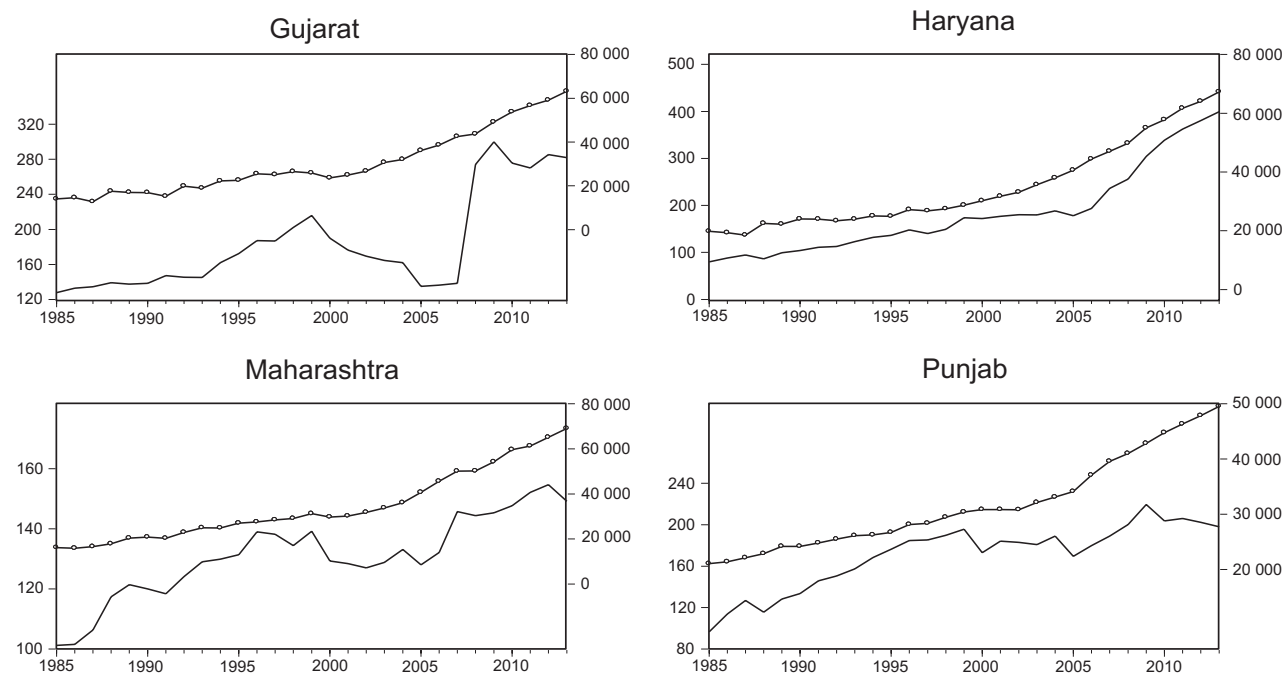

Tamil Nadu
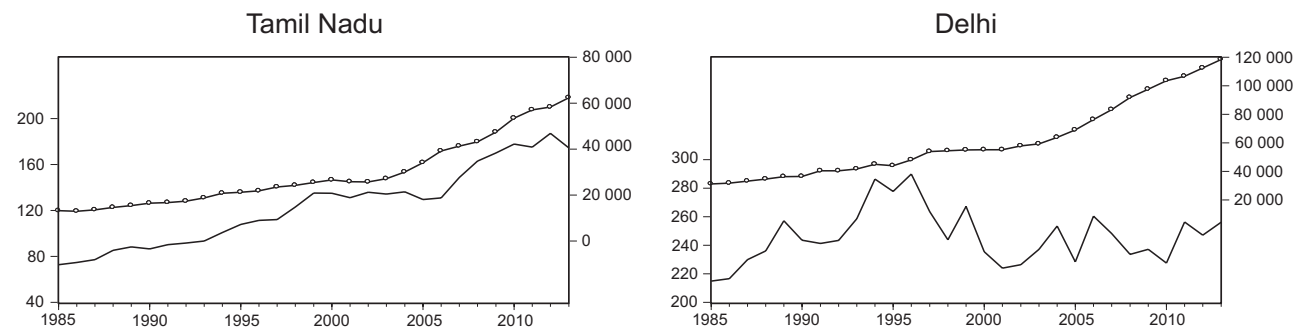

- Per capita energy consumption (left-hand side)

- Per capita gross domestic product (right-hand side) 


\section{Middle-income states}
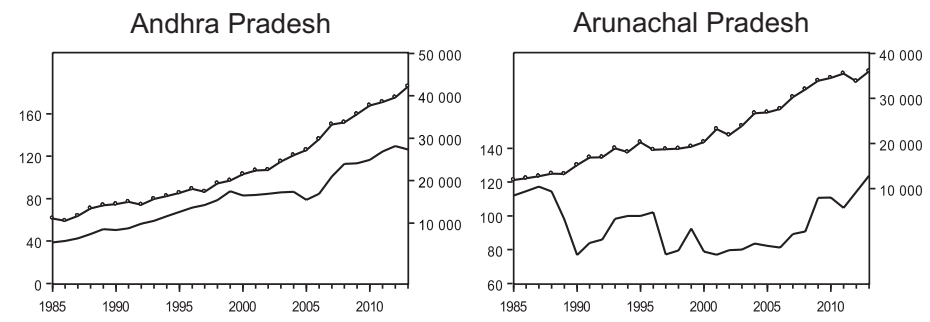

Himachal Pradesh
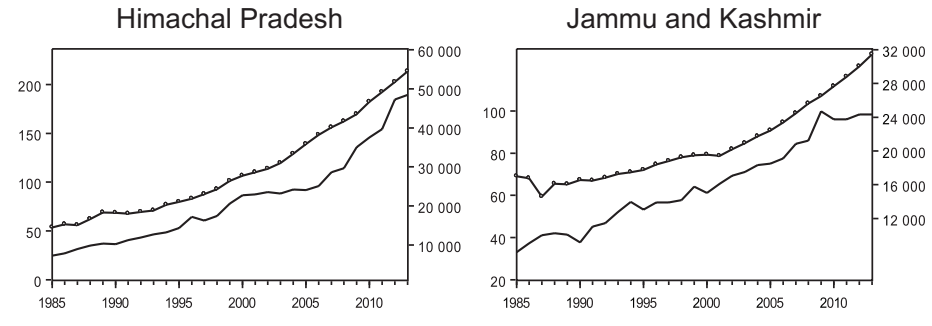

Karnataka

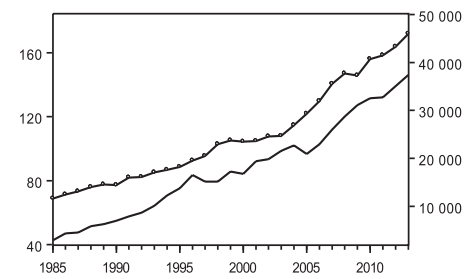

Nagaland
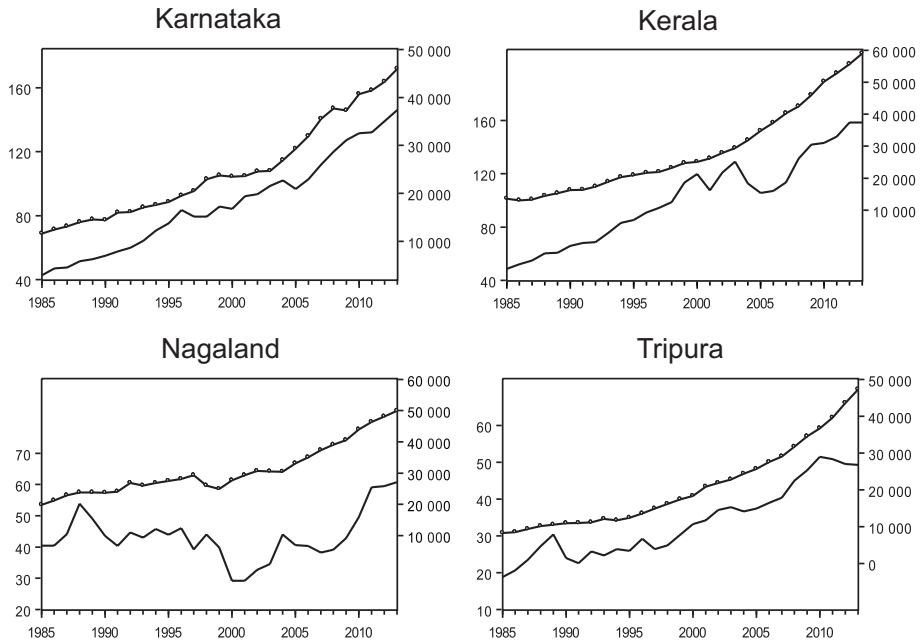

Tripura

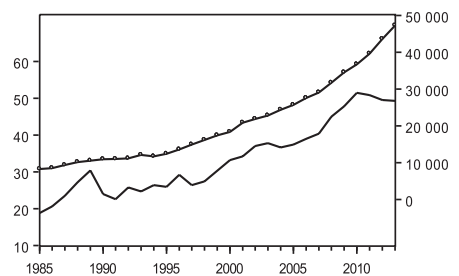

West Bengal

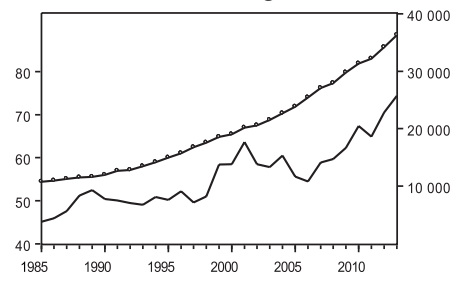




\section{Low-income states}
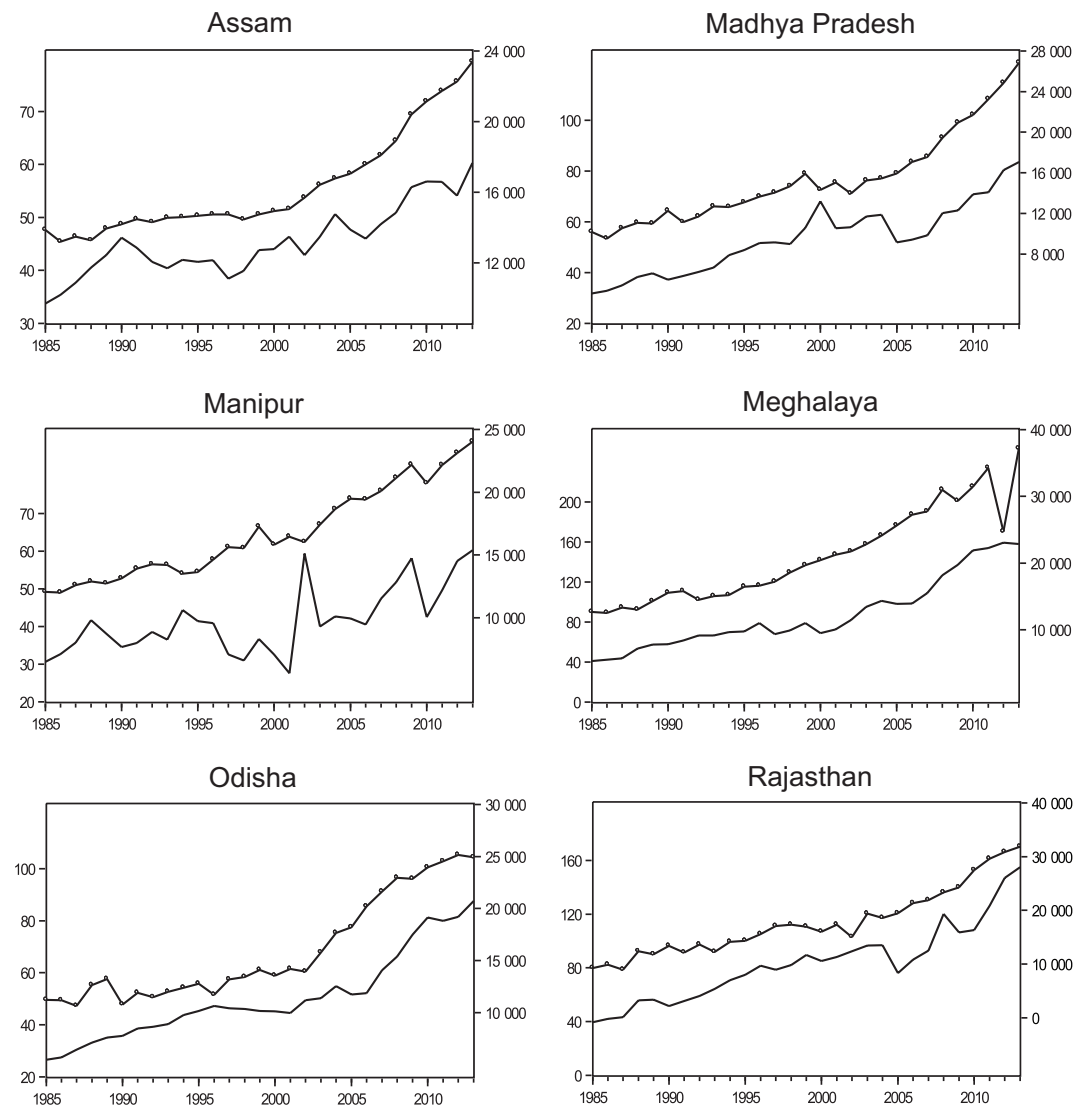

Uttar Pradesh

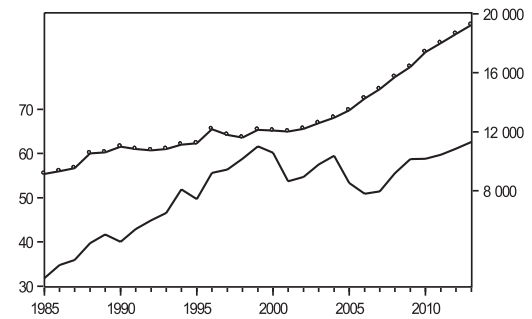

Bihar

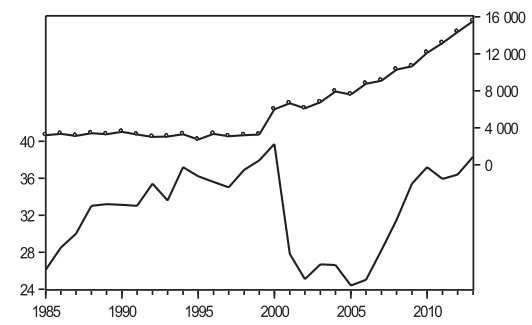

— Per capita energy consumption (left-hand side)

$\ldots$ Per capita gross domestic product (right-hand side) 


\section{EMPIRICAL METHODS}

Our models for long-run inferences are as follows:

$$
\begin{aligned}
& \operatorname{LPEC}_{i, t}=\alpha_{1 i}+\delta_{1 i} t+\beta_{1} \operatorname{LPGDP}_{i, t}+\varepsilon_{1, i t} \\
& \operatorname{LPGDP}_{i, t}=\alpha_{2}+\beta_{2} \operatorname{LPEC}_{i, t}+\varepsilon_{2, i t}
\end{aligned}
$$

where $i=1, \ldots, N$ for each country in the panel and $t=1, \ldots, T$ refers to the time period. The parameters $\alpha i$ and $\delta i$ allow for country-specific fixed effects and deterministic trends, respectively. Deviations from the long-run equilibrium relationship are represented by the estimated residuals, $\varepsilon_{\mathrm{it}}$, LPEC and LPGDP are petroleum consumption per capita and economic growth per capita, respectively, expressed in log form.

Our estimation of short-run models consists of two steps. The first step relates to the estimation of the residual from the long-run relationship as in equations (1) and (2). Incorporating the residual as a right-hand side variable, the short-run error correction model is estimated at the second step. We then get the dynamic error correction model of our interest for estimation. Specifically, causality (short-run) inferences are made by estimating the parameters of the following VECM equations.

$$
\begin{aligned}
& \text { DLPEC }=\alpha_{3}+\sum_{k=1}^{m} \beta_{31 k} D L P E C_{t-k}+\sum_{k=1}^{m} \beta_{32 k} D L P G D P_{t-k}+\beta_{33} Z_{3, t-1}+\varepsilon_{3, t t} \\
& D L P G D P=\alpha_{4}+\sum_{k=1}^{m} \beta_{41 k} D L P E C_{t-k}+\sum_{k=1}^{m} \beta_{42 k} D L P G D P_{t-k}+\beta_{43} Z_{4, t-1}+\varepsilon_{4, t t}
\end{aligned}
$$

where DLPEC and DLPGDP denote petroleum consumption per capita and economic growth per capita, expressed in log-first-difference form and $Z_{3, t-1}$ and $Z_{4, t-1}$ are the error correction terms which are the lagged residual series of the cointegrating vector (1) and (2), respectively.

From equation (4), the null hypothesis that LPEC does not Granger-cause LPGDP is rejected, therefore supporting the growth hypothesis, if the set of estimated coefficients on the lagged values of LPEC is jointly significant. Furthermore, in instances where LPEC appears in the cointegrating relationship, the growth hypothesis is also supported if the coefficient of the lagged error correction term is significant. Changes in an independent variable may be interpreted as representing the short-run causal impact, while the error correction term provides the adjustment of LPEC and LPGDP towards their respective long-run equilibrium. The vector error correction model (VECM) representation, therefore, allows us to differentiate between the short- and long-run dynamic relationships.

Models (1), (2), (3) and (4) are estimated using the feasible generalized least squares (FGLS). In cross-sectional analysis, the error variance is likely to vary across the groups affecting the consistency of the estimators. Using the generalized least 
squares (GLS) method in the estimation could solve this issue. The proposed analysis nested within the GLS model can be stated as the following:

$$
Y_{i t}=\alpha+X_{i t}^{\prime} \beta+\delta_{i}+\gamma_{i}+\varepsilon_{i t}
$$

where $i=\overline{1, N}, t=\overline{1, T}, Y$ is a dependent variable (LPEC or $L R G D P), \alpha$ is a constant, $X$ is a vector of explanatory variables, $\beta$ represents a vector of coefficients to be estimated, $\varepsilon_{i t}$ represents the residual terms, $\delta_{i}$ and $\gamma_{i}$ are the cross-section and, respectively period fixed or random effects, the GLS estimator is based on the following moments:

$$
g(\beta)=\sum_{i=1}^{M} g_{i}(\beta)=\sum_{i=1}^{M} Z_{i}^{\prime} \Omega^{-1} \varepsilon_{i}(\beta)
$$

where $Z_{i}^{\prime}$ is the instrument matrix for the $i$-th cross-section, $\varepsilon_{i}(\beta)=\left(Y_{i t}-\alpha-X_{i t}^{\prime} \beta\right)$ and $\hat{\Omega}$ is a consistent estimation of the variance-covariance matrix $\Omega$. In cross-sectional analysis, the error variance may vary across the groups, affecting the consistency of the estimators. GLS in the estimation can solve this issue, although other sources of variance variability may still exist.

To explore the FGLS model with the best fitted error process for the data, we test for heteroskedasticity using the modified Wald test proposed by Greene (2008). This has a null hypothesis in that there is homoskedasticity in the error term. The results reported in table 4 confirm the rejection of this null hypothesis at a 1 per cent significance level

\begin{tabular}{|c|c|c|c|c|c|c|}
\hline \multicolumn{7}{|c|}{ DPEC $=f(D P G D P)$} \\
\hline \multirow[t]{2}{*}{ Test name } & \multirow[t]{2}{*}{ Error process } & \multirow{2}{*}{$\begin{array}{c}\text { Test } \\
\text { statistic }\end{array}$} & (1) & (2) & (3) & (4) \\
\hline & & & All states & $\begin{array}{l}\text { High-income } \\
\text { states }\end{array}$ & $\begin{array}{c}\text { Middle-income } \\
\text { states }\end{array}$ & $\begin{array}{l}\text { Low-income } \\
\text { states }\end{array}$ \\
\hline Modified & Heteroskedasticity & Chi(2) & $720.92^{\star * \star}$ & $194.01^{* * *}$ & $115.84^{* * *}$ & $378.32^{* * *}$ \\
\hline \multicolumn{7}{|c|}{ DPGDP = f(DPEC) } \\
\hline \multirow[t]{2}{*}{ Test name } & \multirow[t]{2}{*}{ Error process } & \multirow{2}{*}{$\begin{array}{c}\text { Test } \\
\text { statistic }\end{array}$} & (1) & $(2)$ & (3) & (4) \\
\hline & & & All states & $\begin{array}{l}\text { High-income } \\
\text { states }\end{array}$ & $\begin{array}{l}\text { Middle-income } \\
\text { states }\end{array}$ & $\begin{array}{c}\text { Low-income } \\
\text { states }\end{array}$ \\
\hline Modified & Heteroskedasticity & Chi(2) & $5942.32^{* * *}$ & $531.06^{\star * *}$ & $506.85^{\star * *}$ & $1680.17^{* * *}$ \\
\hline \multicolumn{7}{|c|}{$\begin{array}{l}\text { Votes: The modified Wald statistic for group-wise heteroskedasticity in the residuals of a fixed effect model is } \\
\text { calculated following Greene }(2008, p \text {. } 598) \text {. The most likely deviation from homoskedastic errors in the contex } \\
\text { of pooled cross-section time-series data (or panel data) is likely to be error variances specific to the cross- } \\
\text { sectional unit. xttest } 3 \text { tests the hypothesis that } H_{0}: \text { sigma(i) } 2=\text { sigma } 2 \text { for all } i, N \_g \text {, where } N \_g \text { is the } \\
\text { number of cross-sectional units. The resulting test statistic is distributed Chi-squared( } N \text { _g) under the null } \\
\text { hypothesis of homoskedasticity. }{ }^{* * *} \text {, }{ }^{* *} \text { and }{ }^{*} \text { indicate rejection of the null hypothesis at } 1 \text { per cent, } 5 \text { per cent } \\
\text { and } 10 \text { per cent significance levels. }\end{array}$} \\
\hline
\end{tabular}

Table 4. Evidence of heteroskedasticity 
for all the panels, including those with the dependent variables as petroleum consumption per capita (PEC) and as economic growth per capita (PGDP).

Next, we apply the Pesaran (2004) test that examines the null hypothesis of crosssectional independence for the PEC and PGDP models (Pesaran, Ullah and Yamagata, 2008). We present the cross-sectional dependence statistics for the PEC and PGDP models, respectively, in panels 1 and 2 in table 5. The hypothesis that the innovations relating to energy consumption or economic growth equations are cross-sectionally independent is rejected for all panels. Not surprisingly, the all states panel shows the greatest cross-sectional dependence. This is followed by the middle-income states in panel 1 and high-income states in panel 2. On the basis of this result, we proceed to use the FGLS model with an error process that assumes heteroskedasticity and panels that are cross-sectionally dependent. The econometric models were estimated using Stata.

Table 5. Evidence of cross-sectional dependence

\begin{tabular}{lcc}
\hline Pesaran (2004) & Statistic & p-value \\
\hline Panel 1: DPEC = f(DPGDP) & & \\
All states & $80.02^{* * *}$ & 0.0007 \\
High-income states & $18.81^{* * *}$ & 0.0004 \\
Middle-income states & $31.61^{* *}$ & 0.0253 \\
Low-income states & $29.4^{* * *}$ & 0.0000 \\
\hline Panel 2: DPGDP $=\mathrm{f}(\mathrm{DPEC})$ & & \\
All states & $27.59^{* * *}$ & 0.0007 \\
High-income states & $15.26^{* * *}$ & 0.0004 \\
Middle-income states & $3.496^{* *}$ & 0.0253 \\
Low-income states & $2.468^{* * *}$ & 0.0000 \\
\hline Notes: $\quad$ The Pesaran (2004) test was applied for the cross-sectional dependence (also see \\
$\quad$ Pesaran, Ullah and Yamagata, 2008). $\mathrm{H}_{0}$ : cross-sectional independence. ${ }^{* * *}$, ${ }^{* *}$ and * \\
$\quad$ indicate rejection of the null hypothesis at 1 per cent, 5 per cent and 10 per cent \\
$\quad$ significance levels.
\end{tabular}

\section{EMPIRICAL RESULTS}

\section{Panel unit root and cointegration tests and the vector error correction model}

The panel unit root tests, namely, Im, Pesaran and Shin (2003); Levin, Lin and Chu (2002); and panel augmented Dickey-Fuller (ADF) (Maddala and Wu, 1999) are performed. These tests have the common null hypothesis of unit root. The test results 
are presented in table 6. Petroleum consumption per capita (PEC) and economic growth per capita (PGDP), expressed in log form, are integrated of order 1. This applies to all the panels.

Table 6. Unit root test results

\begin{tabular}{|c|c|c|c|c|c|c|c|c|}
\hline \multirow[b]{2}{*}{ PEC } & \multicolumn{2}{|c|}{ All states } & \multicolumn{2}{|c|}{$\begin{array}{l}\text { High-income } \\
\text { states }\end{array}$} & \multicolumn{2}{|c|}{$\begin{array}{l}\text { Middle-income } \\
\text { states }\end{array}$} & \multicolumn{2}{|c|}{$\begin{array}{l}\text { Low-income } \\
\text { states }\end{array}$} \\
\hline & $I(0)$ & $I(1)$ & $I(0)$ & $\mathrm{I}(1)$ & $I(0)$ & $I(1)$ & $I(0)$ & $\mathrm{I}(1)$ \\
\hline LLC $-\mathrm{t}^{*}$ & $\begin{array}{r}-1.671 \\
0.047\end{array}$ & $\begin{array}{c}-14.369^{*} \\
0.000\end{array}$ & $\begin{array}{r}-0.845 \\
0.199\end{array}$ & $\begin{array}{c}-6.594^{*} \\
0.000\end{array}$ & $\begin{array}{r}-1.185 \\
0.118\end{array}$ & $\begin{array}{c}-9.315^{*} \\
0.000\end{array}$ & $\begin{array}{r}-0.839 \\
0.201\end{array}$ & $\begin{array}{c}-8.764^{*} \\
0.000\end{array}$ \\
\hline IPS - W-stat. & $\begin{array}{l}1.490 \\
0.932\end{array}$ & $\begin{array}{c}-13.390^{*} \\
0.000\end{array}$ & $\begin{array}{r}-0.248 \\
0.402\end{array}$ & $\begin{array}{l}-6.325^{*} \\
0.000\end{array}$ & $\begin{array}{l}1.592 \\
0.944\end{array}$ & $\begin{array}{c}-8.557^{*} \\
0.000\end{array}$ & $\begin{array}{l}1.052 \\
0.854\end{array}$ & $\begin{array}{l}-8.151^{*} \\
0.000\end{array}$ \\
\hline ADF - Fisher Chi-square & $\begin{array}{r}32.208 \\
0.939\end{array}$ & $\begin{array}{c}254.551^{*} \\
0.000\end{array}$ & $\begin{array}{r}15.555 \\
0.213\end{array}$ & $\begin{array}{c}60.761^{*} \\
0.000\end{array}$ & $\begin{array}{l}7.449 \\
0.986\end{array}$ & $\begin{array}{c}101.843^{*} \\
0.000\end{array}$ & $\begin{array}{l}9.204 \\
0.905\end{array}$ & $\begin{array}{c}91.948^{*} \\
0.000\end{array}$ \\
\hline PGDP & $I(0)$ & $\mathrm{I}(1)$ & $I(0)$ & $I(1)$ & $I(0)$ & $\mathrm{I}(1)$ & $I(0)$ & $\mathrm{I}(1)$ \\
\hline LLC $-\mathrm{t}^{*}$ & $\begin{array}{l}5.750 \\
1.000\end{array}$ & $\begin{array}{c}-10.385^{*} \\
0.000\end{array}$ & $\begin{array}{l}2.856 \\
0.998\end{array}$ & $\begin{array}{c}-4.699^{*} \\
0.000\end{array}$ & $\begin{array}{l}3.749 \\
1.000\end{array}$ & $\begin{array}{c}-9.610^{*} \\
0.000\end{array}$ & $\begin{array}{l}4.351 \\
1.000\end{array}$ & $\begin{array}{c}-2.741^{*} \\
0.003\end{array}$ \\
\hline IPS - W-stat. & $\begin{array}{r}11.652 \\
1.000\end{array}$ & $\begin{array}{c}-12.868^{*} \\
0.000\end{array}$ & $\begin{array}{l}6.024 \\
1.000\end{array}$ & $\begin{array}{c}-6.121^{*} \\
0.000\end{array}$ & $\begin{array}{l}7.359 \\
1.000\end{array}$ & $\begin{array}{c}-9.071^{*} \\
0.000\end{array}$ & $\begin{array}{l}6.736 \\
1.000\end{array}$ & $\begin{array}{l}-6.896^{*} \\
0.000\end{array}$ \\
\hline ADF - Fisher Chi-square & $\begin{array}{l}1.550 \\
1.000\end{array}$ & $\begin{array}{c}245.771^{*} \\
0.000\end{array}$ & $\begin{array}{l}0.183 \\
1.000\end{array}$ & $\begin{array}{c}59.088^{*} \\
0.000\end{array}$ & $\begin{array}{l}0.847 \\
1.000\end{array}$ & $\begin{array}{c}108.921^{*} \\
0.000\end{array}$ & $\begin{array}{l}0.520 \\
1.000\end{array}$ & $\begin{array}{c}77.762^{*} \\
0.000\end{array}$ \\
\hline
\end{tabular}

Notes: The table covers the Im-Pesaran-Shin (IPS) (Im, Pesaran and Shin, 2003); Levin-Lin-Chu (LLC) (Levin, Lin and Chu, 2002); and augmented Dickey-Fuller (ADF) (Maddala and Wu, 1999) test results. * suggests statistical significance at 1 per cent level. PEC is the petroleum consumption in kilogram of oil equivalent per capita; PGDP is the real per capita net state domestic product at factor cost data with a base year of 2004/05.

As the panels comprise I(1) variables, they all are fit for three panel cointegration tests: Kao (1999), Pedroni (1999; 2004), and the Fisher type-test from Maddala and Wu (1999). The test of Pedroni $(1999 ; 2004)$ is a panel cointegration test that extends the Engle and Granger method to a system of multivariate independent variables for homogeneous and heterogeneous properties across individuals for the panel data. The Kao (1999) test is a residual-based panel test that applies the Dickey-Fuller and augmented Dickey-Fuller type tests and considers homogeneous properties across individuals. The Kao (1999) test focuses on both strict endogenous regressors and strict exogenous regressors.

The Pedroni tests, unlike those of Kao, allow for heterogeneity among individual units of the panel and no exogeneity requirements are imposed on the regressors in the cointegrating regressions. The Maddala and Wu (1999) test is a different method that applies the combination test from Fisher (1932) to derive the test statistics for panel estimation. The combination statistic is constructed from various individual statistics, this 
combination statistic follows the Chi-square distribution rule, in which individual test statistic is computed by Johansen (1988).

Of these tests, the Pedroni $(1999 ; 2004)$ test allows for cross-sectional dependence. Such test uses the fully modified ordinary least squares (FMOLS) estimator that deals with possible autocorrelation and heteroskedasticity of the residuals, taking into account the presence of nuisance parameters, which is asymptotically unbiased and deals with potential endogeneity of regressors. As our panel is burdened by all these three problems, we take this as the superior test of cointegration.

The results from the three cointegration tests are captured in table 7, panels 1-3. Pedroni test results (panel 1) suggest at least one cointegrating relationship for all panels. When compared against the Kao and Fisher test results, we find that the results for all Indian states and the middle- and low-income states are the same. ${ }^{7}$

\section{The relationship between petroleum and economic growth within the long-run models and vector error correction models (VECMs)}

Next, we estimate the long-run models and VECMs for the all states and incomebased panels. This approach differs from the literature on the long run and VECM in that we estimate the long run and VECM nested within the FGLS model relating to petroleum consumption and economic growth. The long-run results are presented in table 8 . The influence of income on petroleum consumption on per capita is examined in panel 1 and the impact of petroleum consumption on per capita real income is examined in panel 2. In the long run, we see signs of a feedback effect for the Indian states at the higher end of the income spectrum. In this regard, our findings are consistent with only two out of 16 studies on energy-economic growth that support the feedback hypothesis.

Per capita real income is found to have a positive and significant influence on petroleum consumption for all the states in the long run (table 8 , panel 1). Petroleum consumption positively affects per capita income of the high-income states (table 8, panel 2). However, for the all states panel, and the middle- and low-income Indian states, we find that petroleum consumption reduces per capita real income in the long run. Hence, while the bilateral link exists between the two variables, it is clear that we fail to find evidence on the feedback hypothesis in its true form.

Before the estimation, we conduct the Di lorio and Fachin (2007) test for breaks in cointegrated panels to examine the stability of the relationship between our variables of interest. The results support the acceptance of the null hypothesis of no break. That is, the relationship among the investigated variables is stable and not subject to structural breaks during the investigation period. The results are not presented here to conserve space, but they are available upon request. 
Table 7. Cointegration results

\begin{tabular}{|c|c|c|c|c|c|c|c|c|}
\hline \multirow{2}{*}{$\begin{array}{l}\text { Panel 1: Pedroni residual } \\
\text { cointegration test }\end{array}$} & \multicolumn{2}{|c|}{ All states } & \multicolumn{2}{|c|}{$\begin{array}{l}\text { High-income } \\
\text { states }\end{array}$} & \multicolumn{2}{|c|}{$\begin{array}{l}\text { Middle-income } \\
\text { states }\end{array}$} & \multicolumn{2}{|c|}{$\begin{array}{l}\text { Low-income } \\
\text { states }\end{array}$} \\
\hline & Stat. & Prob. & Stat. & Prob. & Stat. & Prob. & Stat. & Prob. \\
\hline Panel v & $4.242^{*}$ & 0.000 & $2.665^{\star}$ & 0.004 & $2.347^{*}$ & 0.010 & $2.431^{*}$ & 0.008 \\
\hline Panel rho & $-4.905^{*}$ & 0.000 & $-2.099^{\star}$ & 0.018 & $-1.723^{*}$ & 0.043 & $-4.251^{*}$ & 0.000 \\
\hline Panel PP & $-5.616^{*}$ & 0.000 & $-2.274^{*}$ & 0.012 & $-2.091^{*}$ & 0.018 & $-4.734^{*}$ & 0.000 \\
\hline \multirow[t]{2}{*}{ Panel ADF } & $-3.393^{*}$ & 0.000 & $-1.898^{*}$ & 0.029 & $-1.987^{*}$ & 0.023 & $-2.070^{*}$ & 0.019 \\
\hline & W. Stat. & Prob. & W. Stat. & Prob. & W. Stat. & Prob. & W. Stat. & Prob. \\
\hline Panel v & $3.686^{*}$ & 0.000 & $2.080^{*}$ & 0.019 & $2.596^{*}$ & 0.005 & $1.754^{*}$ & 0.040 \\
\hline Panel rho & $-4.173^{*}$ & 0.000 & $-1.841^{*}$ & 0.033 & $-2.077^{*}$ & 0.019 & $-3.178^{*}$ & 0.001 \\
\hline Panel PP & $-5.389^{*}$ & 0.000 & $-2.341^{*}$ & 0.010 & $-2.648^{*}$ & 0.004 & $-4.147^{*}$ & 0.000 \\
\hline \multirow[t]{2}{*}{ Panel ADF } & $-3.476^{\star}$ & 0.000 & $-1.590^{*}$ & 0.056 & $-2.531^{*}$ & 0.006 & $-1.866^{*}$ & 0.031 \\
\hline & Stat. & Prob. & Stat. & Prob. & Stat. & Prob. & Stat. & Prob. \\
\hline Group rho & $-2.056^{*}$ & 0.020 & $-0.621^{*}$ & 0.267 & -0.577 & 0.282 & $-2.336^{*}$ & 0.010 \\
\hline Group PP & $-4.940^{*}$ & 0.000 & $-1.942^{*}$ & 0.026 & $-2.215^{\star}$ & 0.013 & $-4.344^{*}$ & 0.000 \\
\hline Group ADF & $-3.070^{*}$ & 0.001 & -1.087 & 0.138 & $-2.083^{*}$ & 0.019 & $-2.054^{*}$ & 0.020 \\
\hline \multicolumn{7}{|l|}{ Panel 2: Kao residual } & t-Stat. & Prob. \\
\hline ADF & $-1.643^{*}$ & 0.050 & -0.327 & 0.372 & $-2.579^{*}$ & 0.005 & -0.262 & 0.397 \\
\hline Panel 3: Fisher statistics & $\begin{array}{c}\text { Trace } \\
\text { test }\end{array}$ & Prob. & $\begin{array}{c}\text { Trace } \\
\text { test }\end{array}$ & Prob. & $\begin{array}{c}\text { Trace } \\
\text { test }\end{array}$ & Prob. & $\begin{array}{c}\text { Trace } \\
\text { test }\end{array}$ & Prob. \\
\hline None & $87.130^{*}$ & 0.000 & 15.740 & 0.204 & $34.450^{*}$ & 0.011 & $36.950^{*}$ & 0.002 \\
\hline \multirow[t]{2}{*}{ At most 1} & 53.890 & 0.198 & 12.990 & 0.370 & 21.160 & 0.271 & 19.740 & 0.232 \\
\hline & $\begin{array}{l}\text { Max-eigen } \\
\text { test }\end{array}$ & Prob. & $\begin{array}{l}\text { Max-eigen } \\
\text { test }\end{array}$ & Prob. & $\begin{array}{c}\text { Max-eigen } \\
\text { test }\end{array}$ & Prob. & $\begin{array}{l}\text { Max-eigen } \\
\text { test }\end{array}$ & Prob. \\
\hline None & $81.740^{*}$ & 0.001 & 15.320 & 0.225 & $32.050^{*}$ & 0.022 & $34.360^{*}$ & 0.005 \\
\hline At most 1 & 53.890 & 0.198 & 12.990 & 0.370 & 21.160 & 0.271 & 19.740 & 0.232 \\
\hline
\end{tabular}

Notes: The table presents the results from three cointegration tests: Pedroni, Kao, and Fisher. For the Pedroni test, the first eight statistics refer to homogenous test - the alternative hypothesis: common AR coefficients (withindimension) while the last three statistics refer to heterogeneous test with the alternative hypothesis: individual AR coefficients (between-dimension). * suggests statistical significance at the 1 per cent level. 
Table 8. Long-run models

\begin{tabular}{|c|c|c|c|c|}
\hline & $\begin{array}{c}(1) \\
\text { All states }\end{array}$ & $\begin{array}{c}\quad(2) \\
\text { High-income } \\
\text { states }\end{array}$ & $\begin{array}{c}\text { (4) } \\
\text { Middle-income } \\
\text { states }\end{array}$ & $\begin{array}{c}\text { (5) } \\
\text { Low-income } \\
\text { states }\end{array}$ \\
\hline \multicolumn{5}{|c|}{ Panel 1: LPEC = $f(L P G D P)$} \\
\hline LPGDP & $\begin{array}{l}0.812^{* * *} \\
(0.028)\end{array}$ & $\begin{array}{l}0.556^{* * *} \\
(0.036)\end{array}$ & $\begin{array}{l}0.650^{* * *} \\
(0.057)\end{array}$ & $\begin{array}{l}0.550^{* * *} \\
(0.038)\end{array}$ \\
\hline Observations & 667 & 174 & 261 & 232 \\
\hline Number of crossid & 23 & 6 & 9 & 8 \\
\hline \multicolumn{5}{|c|}{ Panel 2: $L P G D P=f(L P E C)$} \\
\hline LPEC & $\begin{array}{l}-0.682^{* * *} \\
(0.024)\end{array}$ & $\begin{array}{l}1.030^{* * *} \\
(0.067)\end{array}$ & $\begin{array}{l}-0.511^{* * *} \\
(0.045)\end{array}$ & $\begin{array}{l}-0.867^{* * *} \\
(0.06)\end{array}$ \\
\hline Observations & 667 & 174 & 261 & 232 \\
\hline Number of crossid & 23 & 6 & 9 & 8 \\
\hline
\end{tabular}

Next, we report the results on VECMs selected using the usual selection criteria between models with one to six lags. The VECM results relating to per capita petroleum consumption and economic growth models are presented, respectively, in tables 8 and 9 .

The key findings are as follows. First, the error correction model (ECM) has the expected negative sign and is significant for all the models with petroleum consumption (or economic growth) as the dependent variable. The implications are twofold. First, there is a two-way long-run relationship, or a feedback effect, between economic growth and petroleum consumption, as suggested by the preliminary observations. Second, after a shock related to economic growth (petroleum consumption), petroleum consumption (economic growth) bounces back towards equilibrium.

Furthermore, the VECM results point towards a bidirectional association between economic growth and petroleum consumption in the short run for all the panels, except the all states panel. For the high-income Indian states, the feedback hypothesis in its true form is found for the short run as well. This implies that higher petroleum consumption predicts higher economic growth, and in return past economic growth encourages petroleum consumption in the following year. However, for the middleincome states, while a previous year's economic growth is a precursor for a positive change in petroleum consumption in the following year, a previous year's increase in petroleum consumption does not mean higher economic growth in the following year. 
Table 9. State-wise economic growth and petroleum consumption: feasible generalized least squares (FGLS) results

\begin{tabular}{|c|c|c|c|c|c|c|c|c|}
\hline \multirow[b]{2}{*}{ Variables } & \multicolumn{4}{|c|}{ Dependent variable: } & \multicolumn{4}{|c|}{ Dependent variable: } \\
\hline & $\begin{array}{c}\text { (1) } \\
\text { All States }\end{array}$ & $\begin{array}{c}(2) \\
\text { High- } \\
\text { income } \\
\text { States }\end{array}$ & $\begin{array}{c}(3) \\
\text { Middle- } \\
\text { income } \\
\text { States }\end{array}$ & $\begin{array}{c}\text { (4) } \\
\text { Low- } \\
\text { income } \\
\text { States }\end{array}$ & $\begin{array}{c}\text { (1) } \\
\text { All States }\end{array}$ & $\begin{array}{c}(2) \\
\text { High- } \\
\text { income } \\
\text { States }\end{array}$ & $\begin{array}{c}(3) \\
\text { Middle- } \\
\text { income } \\
\text { States }\end{array}$ & $\begin{array}{c}(4) \\
\text { Low- } \\
\text { income } \\
\text { States }\end{array}$ \\
\hline$D L P G D P_{t-1}$ & $\begin{array}{l}-0.0471 \\
(0.0665)\end{array}$ & $\begin{array}{l}0.0348^{* * *} \\
(0.0114)\end{array}$ & $\begin{array}{l}0.366^{\star * *} \\
(0.121)\end{array}$ & $\begin{array}{l}-0.140 \\
(0.0893)\end{array}$ & $\begin{array}{l}-0.187^{* * *} \\
(0.0440)\end{array}$ & $\begin{array}{l}-0.244^{* *} \\
(0.0774)\end{array}$ & $\begin{array}{l}-0.00776 \\
(0.0634)\end{array}$ & $\begin{array}{l}-0.295^{\star * *} \\
(0.0707)\end{array}$ \\
\hline$D L P G D P_{t-2}$ & $\begin{array}{l}-0.0217 \\
(0.0683)\end{array}$ & & & $\begin{array}{l}-0.234^{* *} \\
(0.0953)\end{array}$ & $\begin{array}{c}0.121^{* * *} \\
(0.0453)\end{array}$ & & & $\begin{array}{c}0.0828 \\
(0.0760)\end{array}$ \\
\hline$D L P G D P_{t-3}$ & $\begin{array}{c}0.245^{\star * *} \\
(0.0650)\end{array}$ & & & $\begin{array}{c}0.120 \\
(0.0939)\end{array}$ & $\begin{array}{c}0.0457 \\
(0.0430)\end{array}$ & & & $\begin{array}{c}0.0567 \\
(0.0749)\end{array}$ \\
\hline$D L P G D P_{t-4}$ & $\begin{array}{c}0.112^{\star} \\
(0.0650)\end{array}$ & & & & $\begin{array}{c}0.141^{* * *} \\
(0.0430)\end{array}$ & & & \\
\hline$D L P G D P_{t-5}$ & $\begin{array}{c}0.0930 \\
(0.0641)\end{array}$ & & & & $\begin{array}{l}-0.0373 \\
(0.0423)\end{array}$ & & & \\
\hline$D L P E C_{t-1}$ & $\begin{array}{l}-0.0972^{* *} \\
(0.0425)\end{array}$ & $\begin{array}{c}0.0760 \\
(0.0780)\end{array}$ & $\begin{array}{c}0.0685 \\
(0.0622)\end{array}$ & $\begin{array}{l}-0.234^{\star * *} \\
(0.0719)\end{array}$ & $\begin{array}{l}-0.00431 \\
(0.0277)\end{array}$ & $\begin{array}{l}0.0299^{\star * *} \\
(0.0052)\end{array}$ & $\begin{array}{l}-0.0182^{\star * *} \\
(0.00322)\end{array}$ & $\begin{array}{l}-0.0288^{\star * *} \\
(0.00548)\end{array}$ \\
\hline$D L P E C_{t-1}$ & $\begin{array}{l}-0.0657 \\
(0.0423)\end{array}$ & & & $\begin{array}{l}-0.130^{*} \\
(0.0716)\end{array}$ & $\begin{array}{c}0.0206 \\
(0.0276)\end{array}$ & & & $\begin{array}{c}0.0162 \\
(0.0553)\end{array}$ \\
\hline$D L P E C_{t-1}$ & $\begin{array}{c}0.00278 \\
(0.0412)\end{array}$ & & & $\begin{array}{l}-0.0315 \\
(0.0690)\end{array}$ & $\begin{array}{l}-0.0393 \\
(0.0270)\end{array}$ & & & $\begin{array}{l}-0.0367 \\
(0.0540)\end{array}$ \\
\hline$D L P E C_{t-1}$ & $\begin{array}{l}-0.0288 \\
(0.0417)\end{array}$ & & & & $\begin{array}{l}-0.0347 \\
(0.0273)\end{array}$ & & & \\
\hline$D L P E C_{t-1}$ & $\begin{array}{c}0.0561 \\
(0.0420)\end{array}$ & & & & $\begin{array}{l}-0.0358 \\
(0.0275)\end{array}$ & & & \\
\hline$E C M_{t-1}$ & $\begin{array}{l}-0.0213^{* *} \\
(0.00930)\end{array}$ & $\begin{array}{l}-0.0624^{\star *} \\
(0.0286)\end{array}$ & $\begin{array}{l}-0.0256^{\star *} \\
(0.0129)\end{array}$ & $\begin{array}{l}-0.0189^{* *} \\
(0.0053)\end{array}$ & $\begin{array}{l}-0.0950^{\star * *} \\
(0.00500)\end{array}$ & $\begin{array}{l}-0.0258^{* *} \\
(0.01433)\end{array}$ & $\begin{array}{l}-0.0333^{\star * *} \\
(0.0076)\end{array}$ & $\begin{array}{l}-0.0205^{\star \star *} \\
(0.0015)\end{array}$ \\
\hline Observations & 529 & 162 & 243 & 200 & 529 & 162 & 243 & 200 \\
\hline No. of crossid & 23 & 6 & 9 & 8 & 23 & 6 & 9 & 8 \\
\hline
\end{tabular}

Notes: Using the feasible generalized least squares (FGLS) methodology, we estimate the short-run relationship between petroleum consumption and economic growth. Lag length selection for each panel is based on Akaike information criterion (AIC) and Bayesian information criterion (BIC). ${ }^{* * *}$, ** and * indicate rejection of the null hypothesis at 1 per cent, 5 per cent and 10 per cent significance levels. Standard errors are reported in the parentheses.

In addition, for the low-income states, higher growth in previous years predicts reduced demand for petroleum consumption. What is puzzling is that higher petroleum consumption predicts a fall in the short-term real income growth. Unsurprisingly, for the all states panel, we find an unidirectional link in the short run, with the effect running from economic growth to petroleum consumption. This supports the prevalence of the conservative hypothesis for the short run. The finding suggests that a reduction in the 
use of petroleum and a switch to cleaner and cheaper alternatives will not harm economic growth.

\section{THE ENERGY CONSUMPTION AND ECONOMIC GROWTH (E-Y) CONNECTIONS WITH DISAGGREGATED PETROLEUM}

We examine the relationship between state-wise data on petroleum consumption and income using the disaggregated data on petroleum consumption by state. We classified the different types of petroleum consumption into six energy sources: (a) liquefied petroleum gas (LPG); (b) petrol (PET); (c) superior kerosene oil (SKO); (d) diesel/high speed diesel (HSD); (e) furnace oil (FO); and (f) naptha; aviation turbine fuel; light diesel oil; low sulphur heavy stock/hot heavy stock; lubes and greases; itumen; others (OTHERS). The disaggregated petroleum consumption data are sourced from the States of India database. The disaggregated petroleum consumption data are converted into per capita terms using population data on the Indian states attained from the Economic and Political Weekly Research Foundation database. We conducted the same tests for the aggregate data and the disaggregated data. The results for the disaggregated data are presented in the appendix.

We begin with the descriptive statistics in appendix table A.1. Notice that, with the exception of HSD, the petroleum disaggregates vary in terms of importance for each state. Out of all petroleum products, the average consumption of HSD is consistently the strongest type of consumption in all states. In the high-income states, the consumption of HSD is followed by PET, SKO, LPG, and FO. In the middle-income states, HSD consumption is trailed by SKO, PET, LPG, and FO. In the low-income states, consumption of SKO, PET, LPG, and FO are, on average, lower than that of HSD.

The unit root tests of the disaggregated petroleum data are presented in appendix table A.2. As the disaggregated petroleum types are found to be stationary at I(1), we proceed with the cointegration tests. The cointegration test results indicate rather limited cases of cointegration between the disaggregated petroleum types and economic growth. The full sample, comprising of all the Indian states, indicates that petroleum disaggegates SKO and OTHERS, possibly having a stable long-run association with income (appendix table A.3). For the high-income states panel, none of the petroleum types are cointegrated with the state income (appendix table A.4). For the middleincome Indian states panel, PET, LPG, and OTHERS may have stable long-run relations with income (appendix table A.5). For the low-income states panel, only LPG has a possible cointegration link with income (appendix table A.6).

The causal relationships and the direction of the causation between these cointegrated relationships are examined using VECMs (appendix table A.7). Estimation methods were similar to those discussed in the previous sections. For VECM, when the 
state-wise economic growth is the dependent variable, we find VECM to be valid in two instances - the link between LPG and economic growth of the middle-income and low-income states (appendix table A.7, panel 1). The long-run linkage between these variables are positive and significant (appendix table A.8, panel 2). This means that LPG has a positive effect on income of the middle-income states and low-income states.

Returning to VECMs, when different petroleum types are alternated as dependent variables, all cointegrated relations produce valid VECMs (appendix table A.7, panel 2). These findings imply that LPG and economic growth of the low-income states have a bidirectional or a feedback relationship. However, the rest of the valid relationships discussed here satisfy the conservative hypothesis. In the conservative hypothesis, economic growth is a good predictor of use of petroleum disaggegates, namely, SKO, and OTHERS (for the full sample); PET (for the middle-income sample); and LPG (for the low-income sample).

While in the long run economic growth is predicted to have a positive effect on the disaggregated energy consumption, in the short run economic growth is found to reduce consumption of SKO (for the all states panel) and LPG (for the low-income states panel).

\section{FURTHER DISCUSSIONS}

This study shows different results regarding the nexus between energy consumption and economic growth across the 23 selected Indian states grouped in different panels based on their income level. This suggests that an appropriate approach for India should be to adopt state-specific policies in lieu of an integrated policy for all states.

For the high-income (and most industrialized) states of India, we find a prevalence of the feedback effect in the long and short run using aggregate petroleum data. This finding implies that energy supply shock may have a significant impact on economic growth (and vice versa). As such, adopting a general energy conservation policy may have a detrimental impact on the economic growth process in high-income states in India. Energy policy targeted towards higher petroleum usage is critical for the economic growth of these states. In this regard, it is suggested that the Government of India encourages the use and development of more advance and eco-friendly technologies by providing an array of energy tax credits as incentives for use of alternative energy resources. By so doing, it can minimize the energy supply shock effect on the output and reduce the unfavourable effects on the environment. 
The Government of India has achieved significant milestones in building nuclear power plants. For instance, the Russian Federation-backed 2,000 megawatt Kudankulam Nuclear Power Plant in Tamil Nadu was completed in 2013; it has become the single largest nuclear power station in India. In addition, India also signed the Civil Nuclear Cooperation Agreement with the United States in 2008. This initiative is expected to foster the growth of the country's civil nuclear sector and consequently enhance its energy security. India would greatly benefit from a stable clean energy source for its large and rapidly growing economy, which also would have favourable environmental effects. Our use of disaggregated data indicates insignificant effects of short-term and long-term linkages between petroleum and economic growth. This suggests that the use of aggregate data is more appropriate for modelling the linkages between petroleum consumption and income in high-income states.

For the middle- and low-income states, we are unable to find a feedback effect between petroleum consumption and economic growth in the aggregate data. For the middle-income states, economic growth is able to predict higher petroleum consumption but past increases in petroleum consumption does not predict future economic growth. We find this to be the case in the short run and in the long run. However, when we consider disaggregated petroleum consumption data, we find that LPG and economic growth show the feedback effect.

For the low-income state panel, in the long run, economic growth increases aggregate petroleum consumption, but increased aggregate petroleum consumption reduces economic growth. In the short run, economic growth reduces petroleum demand and lower petroleum consumption translates into higher economic growth. For the all states panel, there is a prevalence of the unidirectional link, with the effect running from economic growth to aggregate petroleum consumption. This supports the conservative hypothesis for the short run. These findings suggest that a reduction in the use of petroleum and switching to cleaner and cheaper alternatives (here, abundant and cheap labour should not be ruled out) will not harm economic growth. In fact, in the case of low- (and middle-) income states, economic growth is encouraged, with a reduction in petroleum usage. Our study of the disaggregated petroleum consumption suggests that petroleum products relating to superior kerosene oil and others are also influenced by economic growth.

While our analysis gives strong support for the feedback hypothesis for the richer states of India, our results also show two points of interest to policymakers: (i) petroleum is affecting growth negatively in the middle- and low-income states in India; and (ii) economic growth can be promoted even with lower petroleum consumption. These results have not been observed in the Indian literature or any other study to date. 


\section{CONCLUDING REMARKS}

We examined the energy consumption and economic growth (E-Y) nexus for a panel of 23 Indian states and the subpanels of these Indian states classified by high, middle, and low income on the basis of their average per capita real GDP over the period 1985-2013. Upon finding the presence of cross-sectional dependence in the panels and heteroskedasticity in the relationships, we use the FGLS methodology to examine the long-run and short-run relationships.

Our key findings are as follows. For the country's high-income (and most industrialized) states, we find evidence of the feedback effect in the long run and the short run. For the middle- and low-income states, however, we do not find this feedback effect between petroleum consumption and economic growth in neither the short run nor the long run. Similarly, for the low-income state panel, in the long run, economic growth appears to increase petroleum consumption but higher petroleum usage seems to reduce economic growth. In the short run, we find that economic growth reduces petroleum demand while lower petroleum consumption leads to higher economic growth. For the all states panel, there is evidence of the unidirectional effect running from economic growth to petroleum consumption in the short run. This supports the prevalence of the conservative hypothesis. These results are also confirmed by using disaggregated data on petroleum consumption.

Some of the distortions we notice may be because the economies of the middleand low-income Indian states have been chiefly informal and therefore statistically unaccounted for. A large part of agriculture, construction and manufacturing are comprised of informal sectors that consume petroleum but are largely missing in the GDP statistics.

At play here could be other features of the poorer states that do not show clear E-Y linkages. For instance, the informal sectors rely heavily on unskilled labour. We suspect that increased use of imported and expensive petroleum in place of abundant unskilled workers is to some degree also leading to a misallocation of resources in these poorer states. However, exploring this issue is not within the scope of the study. We leave this as part of a future research agenda. 


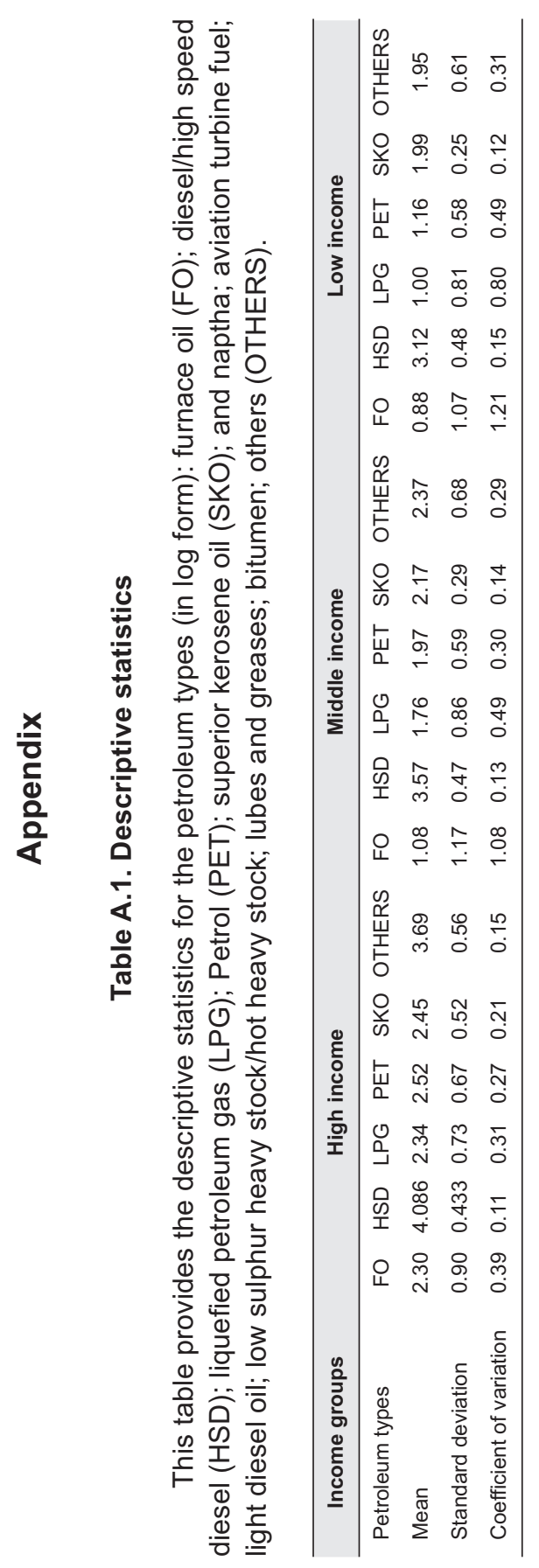




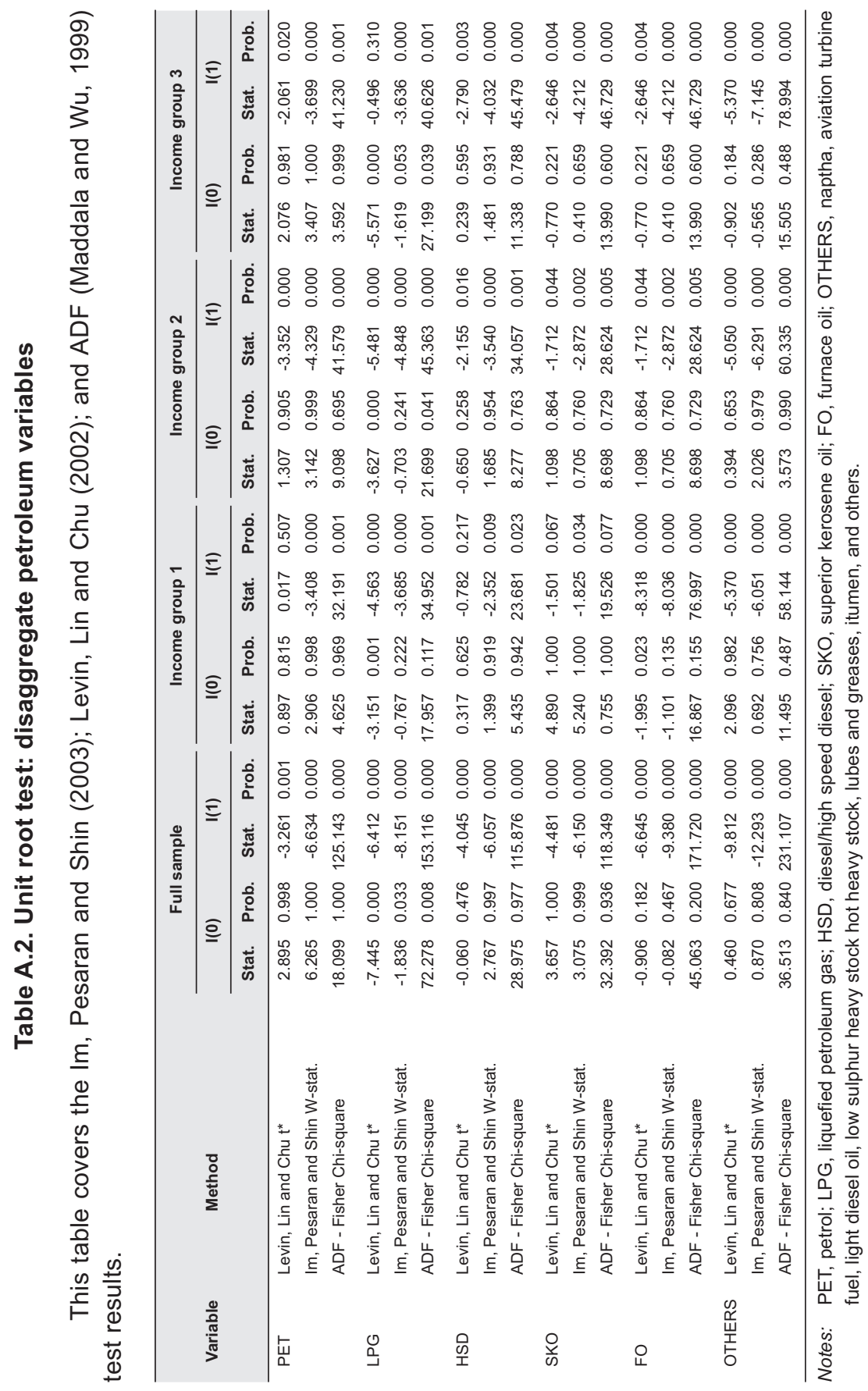




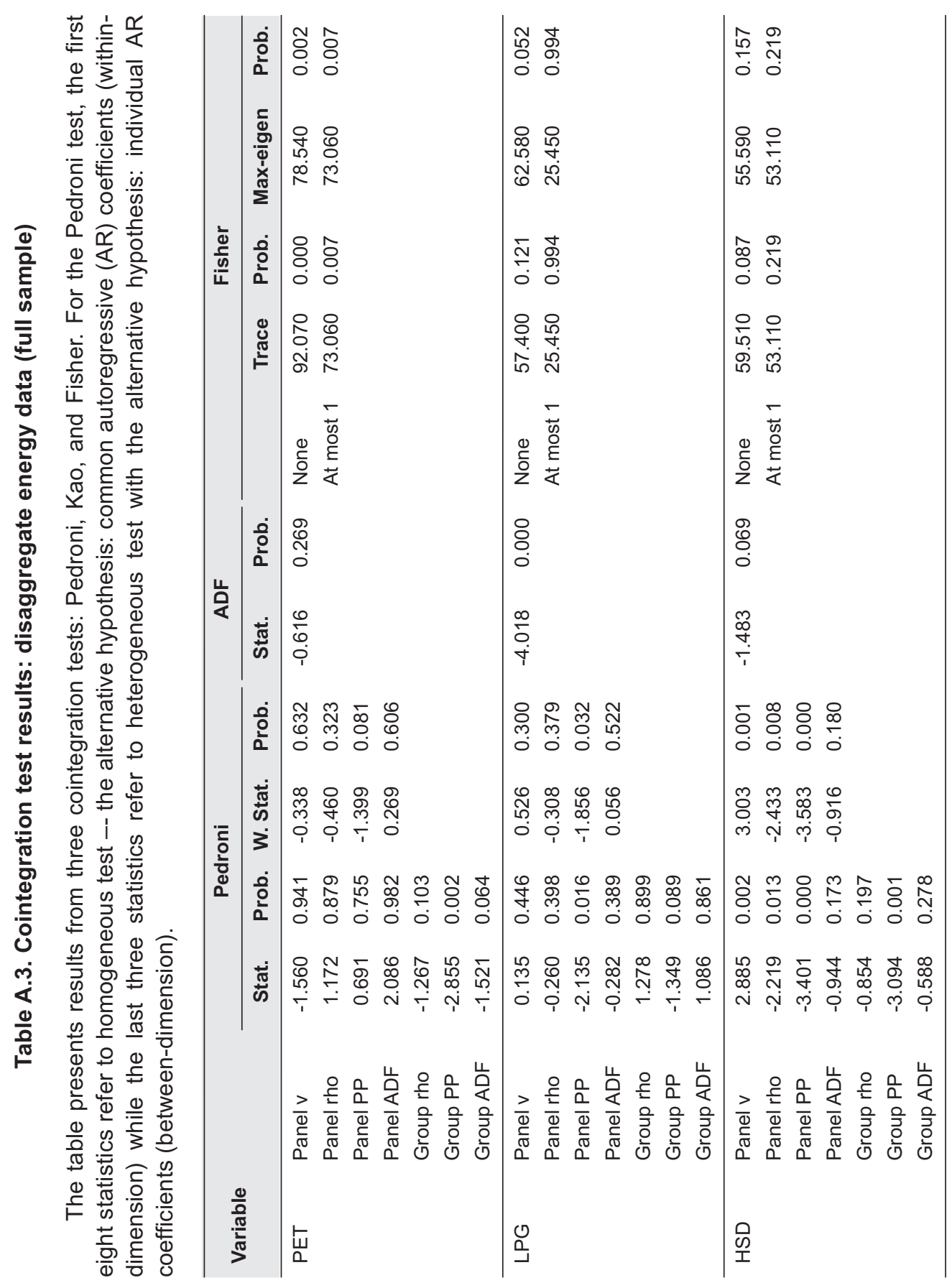




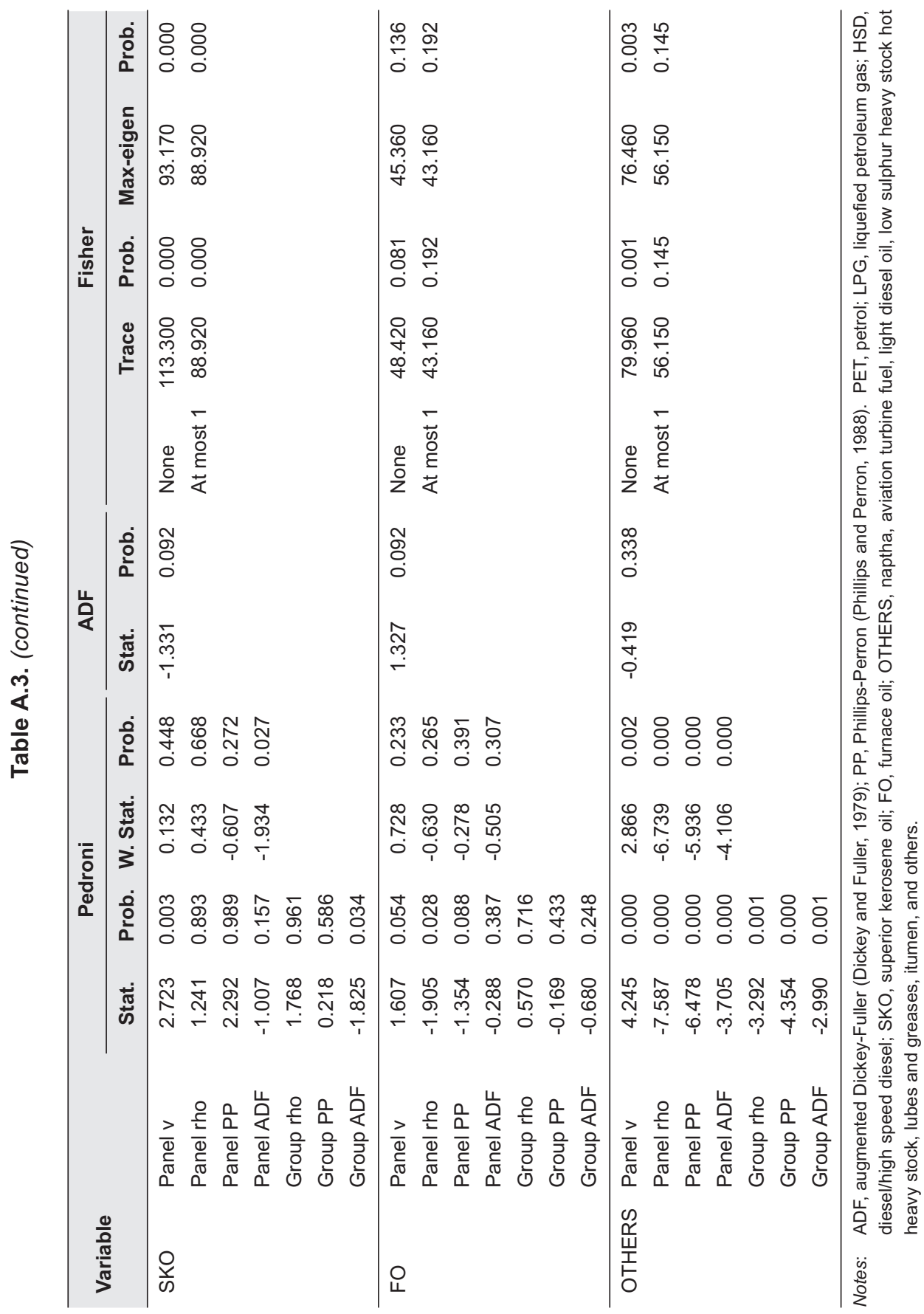




\section{Table A.4. Cointegration test results: disaggregate energy data (high-income group)}

The table presents results from two cointegration tests: Pedroni, and Kao. For the Pedroni test, the first eight statistics refer to homogenous test - the alternative hypothesis: common autoregressive (AR) coefficients (within-dimension) while the last three statistics refer to heterogeneous test with the alternative hypothesis: individual AR coefficients (between-dimension).

\begin{tabular}{|c|c|c|c|c|c|c|c|}
\hline \multirow{2}{*}{ Variabl } & & \multicolumn{4}{|c|}{ Pedroni } & \multicolumn{2}{|c|}{ ADF } \\
\hline & & Stat. & Prob. & W. Stat. & Prob. & Stat. & Prob. \\
\hline \multirow[t]{7}{*}{ PET } & Panel v & 0.016 & 0.494 & 0.016 & 0.494 & 0.117 & 0.453 \\
\hline & Panel rho & -0.002 & 0.499 & -0.002 & 0.499 & & \\
\hline & Panel PP & 0.259 & 0.602 & 0.259 & 0.602 & & \\
\hline & Panel ADF & 0.990 & 0.839 & 0.990 & 0.839 & & \\
\hline & Group rho & 0.504 & 0.693 & & & & \\
\hline & Group PP & 0.676 & 0.751 & & & & \\
\hline & Group ADF & 1.545 & 0.939 & & & & \\
\hline \multirow[t]{7}{*}{ LPG } & Panel v & 0.338 & 0.368 & 0.338 & 0.368 & -1.064 & 0.144 \\
\hline & Panel rho & -1.212 & 0.113 & -1.212 & 0.113 & & \\
\hline & Panel PP & -1.096 & 0.137 & -1.096 & 0.137 & & \\
\hline & Panel ADF & 0.073 & 0.529 & 0.073 & 0.529 & & \\
\hline & Group rho & -0.624 & 0.266 & & & & \\
\hline & Group PP & -0.932 & 0.176 & & & & \\
\hline & Group ADF & 0.455 & 0.676 & & & & \\
\hline \multirow[t]{7}{*}{ HSD } & Panel v & 1.521 & 0.064 & 1.521 & 0.064 & -0.187 & 0.426 \\
\hline & Panel rho & -0.917 & 0.180 & -0.917 & 0.180 & & \\
\hline & Panel PP & -0.807 & 0.210 & -0.807 & 0.210 & & \\
\hline & Panel ADF & -0.070 & 0.472 & -0.070 & 0.472 & & \\
\hline & Group rho & -0.350 & 0.363 & & & & \\
\hline & Group PP & -0.589 & 0.278 & & & & \\
\hline & Group ADF & 0.286 & 0.613 & & & & \\
\hline \multirow[t]{7}{*}{ SKO } & Panel v & -0.695 & 0.757 & -0.695 & 0.757 & 2.252 & 0.012 \\
\hline & Panel rho & 0.749 & 0.773 & 0.749 & 0.773 & & \\
\hline & Panel PP & 0.922 & 0.822 & 0.922 & 0.822 & & \\
\hline & Panel ADF & 0.999 & 0.841 & 0.999 & 0.841 & & \\
\hline & Group rho & 1.203 & 0.886 & & & & \\
\hline & Group PP & 1.464 & 0.928 & & & & \\
\hline & Group ADF & 1.555 & 0.940 & & & & \\
\hline
\end{tabular}


Table A.4. (continued)

\begin{tabular}{|c|c|c|c|c|c|c|c|}
\hline \multirow{2}{*}{ Variable } & & \multicolumn{4}{|c|}{ Pedroni } & \multicolumn{2}{|c|}{ ADF } \\
\hline & & Stat. & Prob. & W. Stat. & Prob. & Stat. & Prob. \\
\hline \multirow[t]{7}{*}{ FO } & Panel v & -0.055 & 0.522 & -0.055 & 0.522 & 0.014 & 0.495 \\
\hline & Panel rho & -0.257 & 0.398 & -0.257 & 0.398 & & \\
\hline & Panel PP & -0.728 & 0.233 & -0.728 & 0.233 & & \\
\hline & Panel ADF & 0.649 & 0.742 & 0.649 & 0.742 & & \\
\hline & Group rho & 0.265 & 0.605 & & & & \\
\hline & Group PP & -0.495 & 0.310 & & & & \\
\hline & Group ADF & 1.139 & 0.873 & & & & \\
\hline \multirow[t]{7}{*}{ OTHERS } & Panel v & 1.310 & 0.095 & 1.310 & 0.095 & 0.214 & 0.415 \\
\hline & Panel rho & -1.135 & 0.128 & -1.135 & 0.128 & & \\
\hline & Panel PP & -0.888 & 0.187 & -0.888 & 0.187 & & \\
\hline & Panel ADF & -1.103 & 0.135 & -1.103 & 0.135 & & \\
\hline & Group rho & -0.553 & 0.290 & & & & \\
\hline & Group PP & -0.685 & 0.247 & & & & \\
\hline & Group ADF & -0.940 & 0.174 & & & & \\
\hline
\end{tabular}

Notes: ADF, augmented Dickey-Fuller (Dickey and Fuller, 1979); PP, Phillips-Perron (Phillips and Perron, 1988). PET, petrol; LPG, liquefied petroleum gas; HSD, diesel/high speed diesel; SKO, superior kerosene oil; FO, furnace oil; OTHERS, naptha, aviation turbine fuel, light diesel oil, low sulphur heavy stock hot heavy stock, lubes and greases, itumen, and others. 


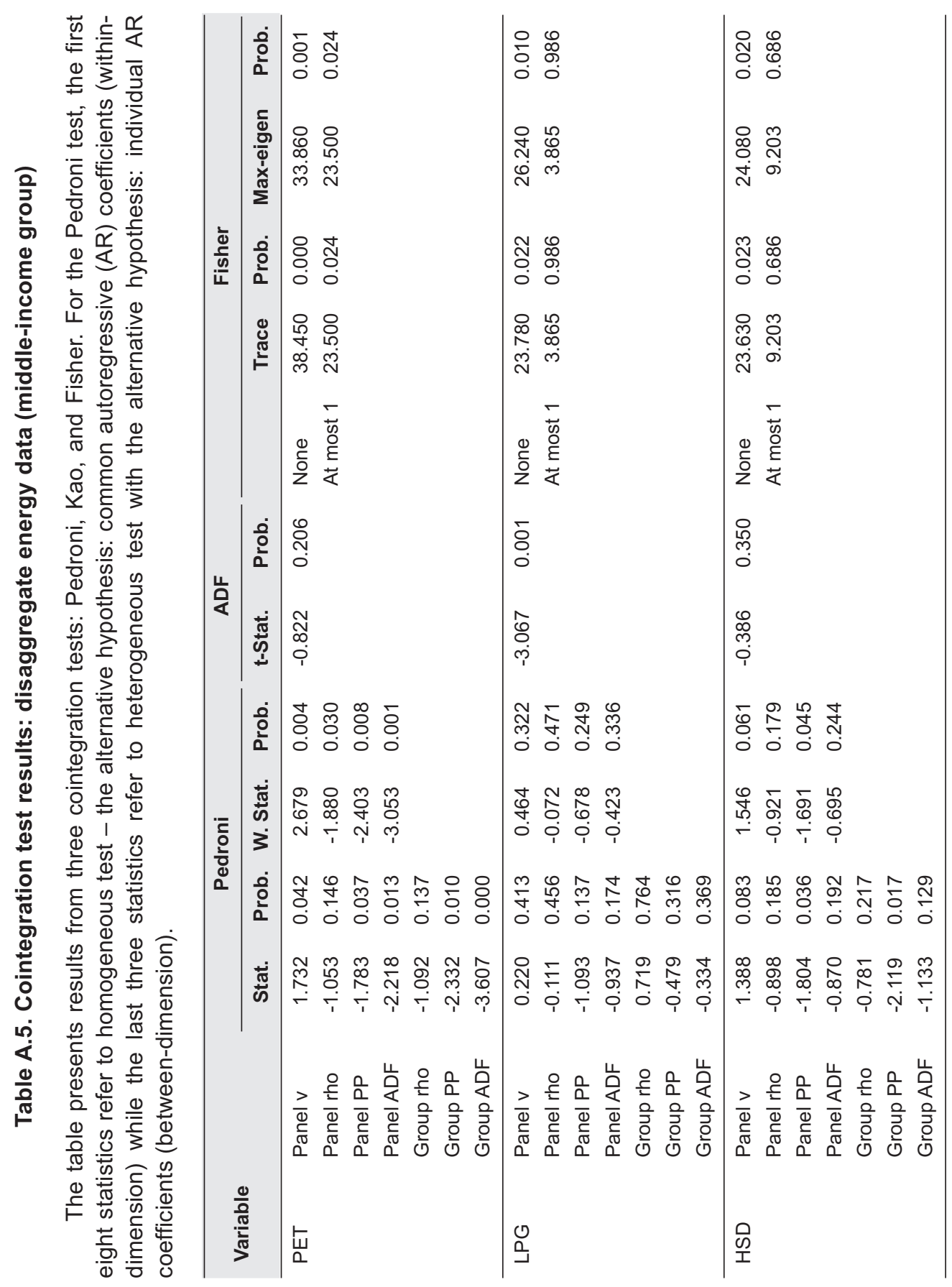




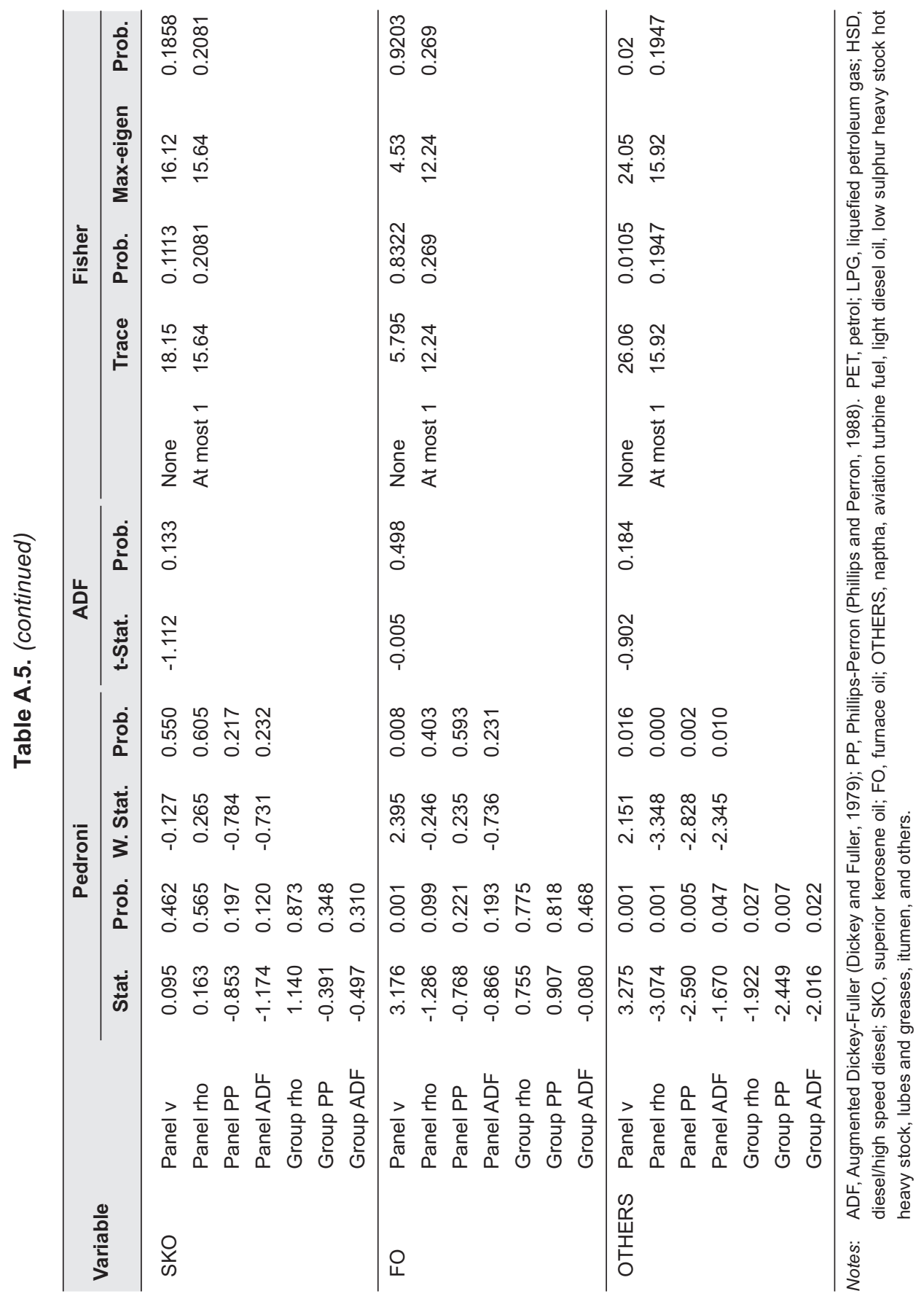




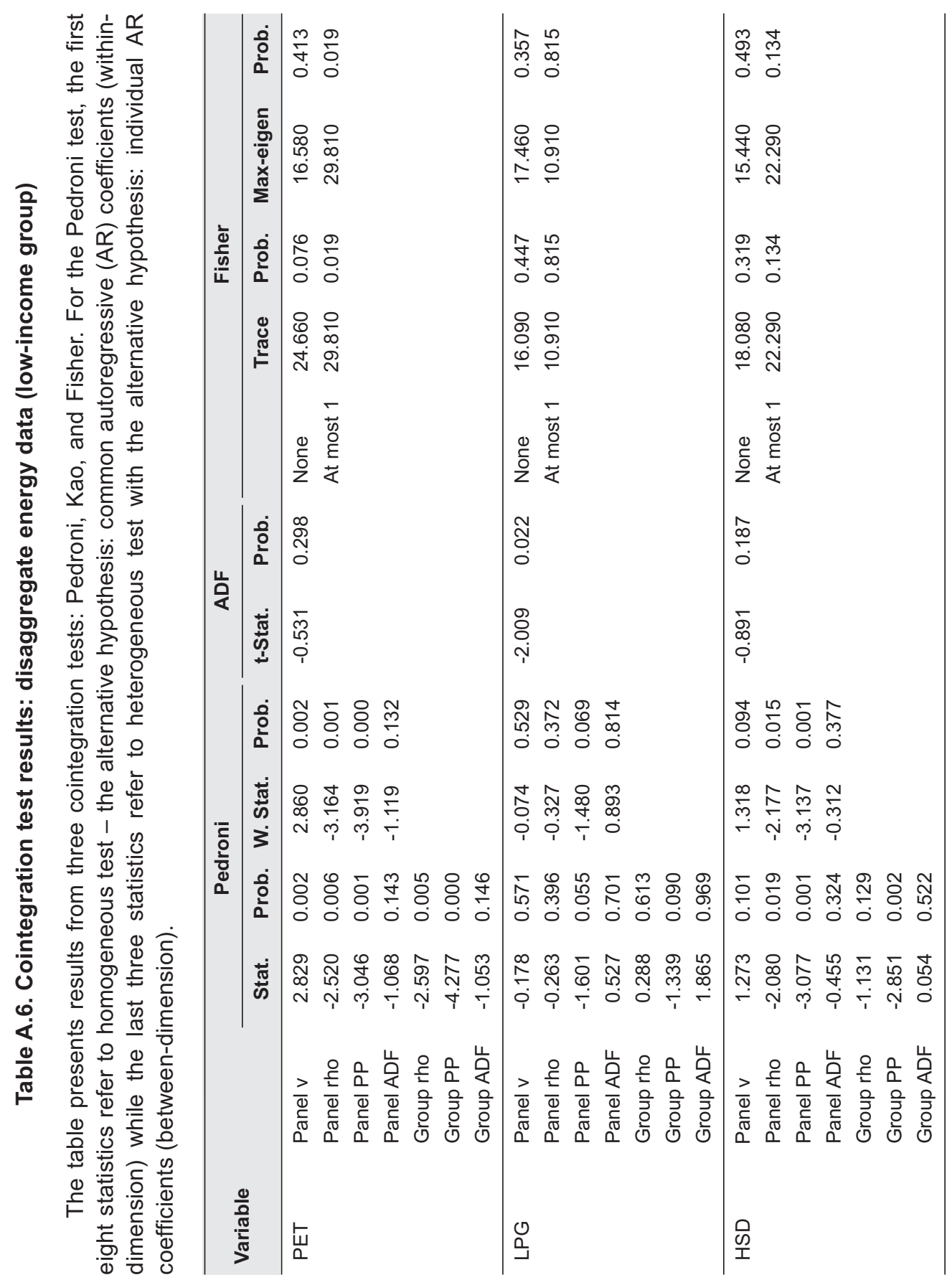




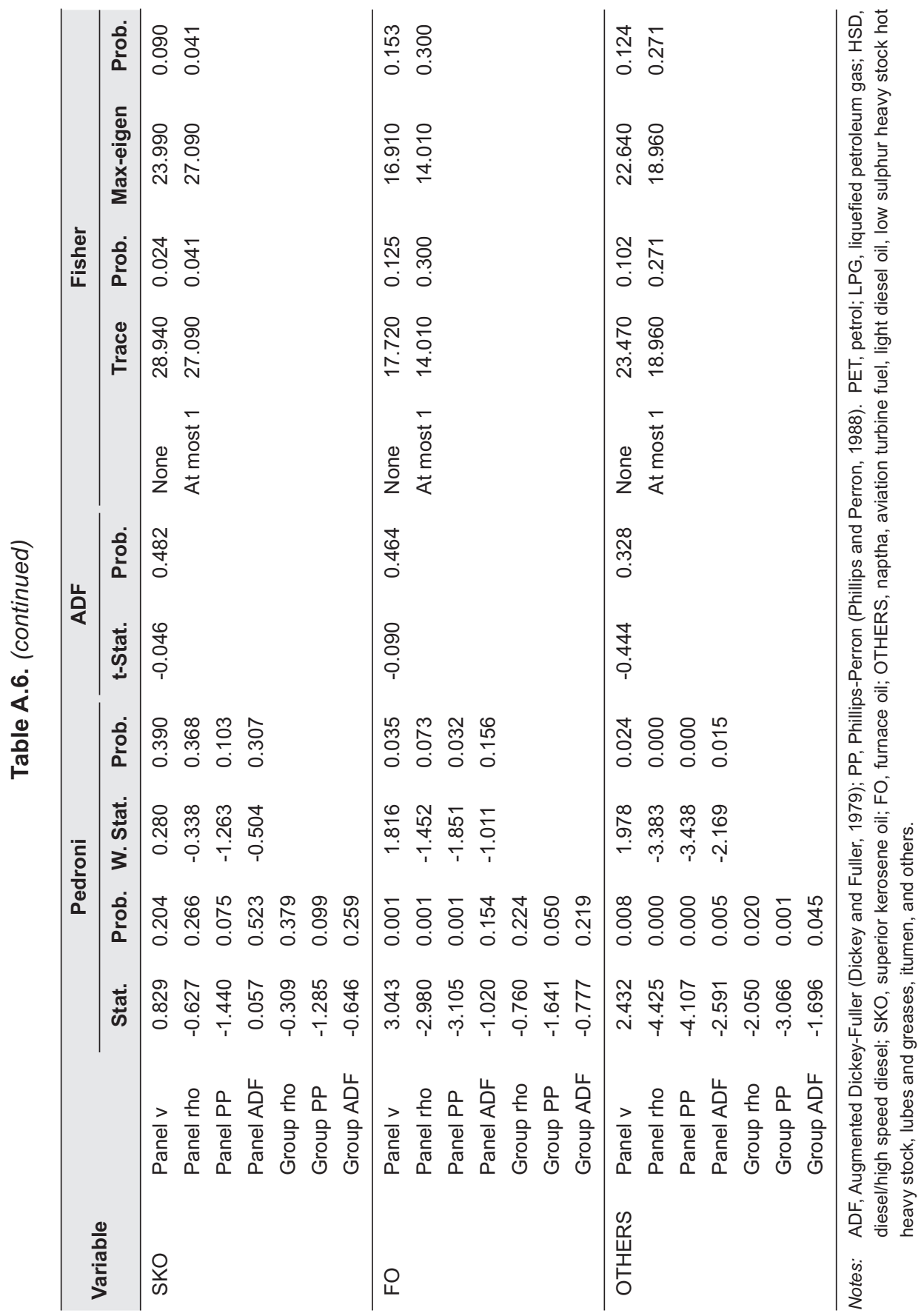




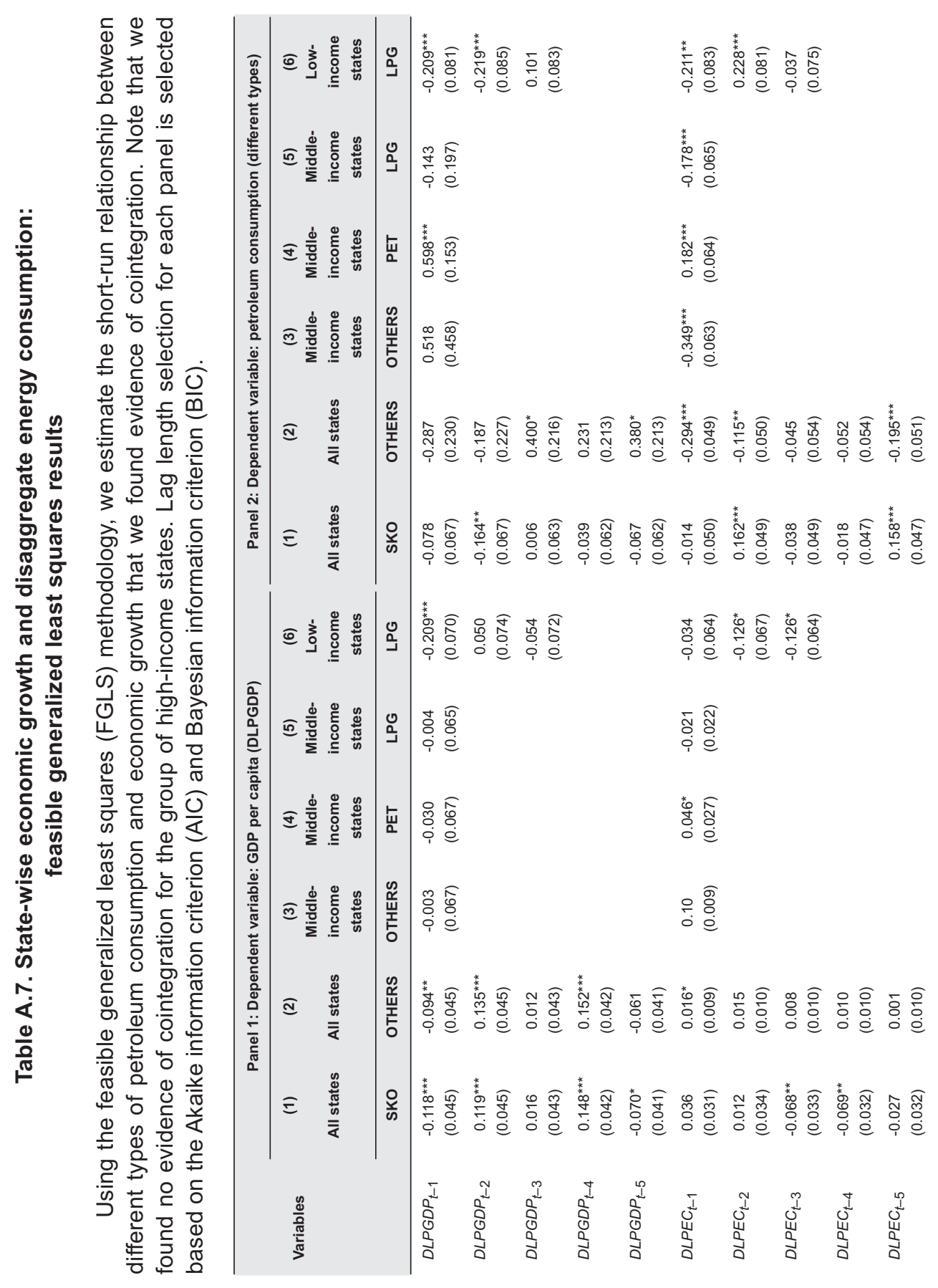




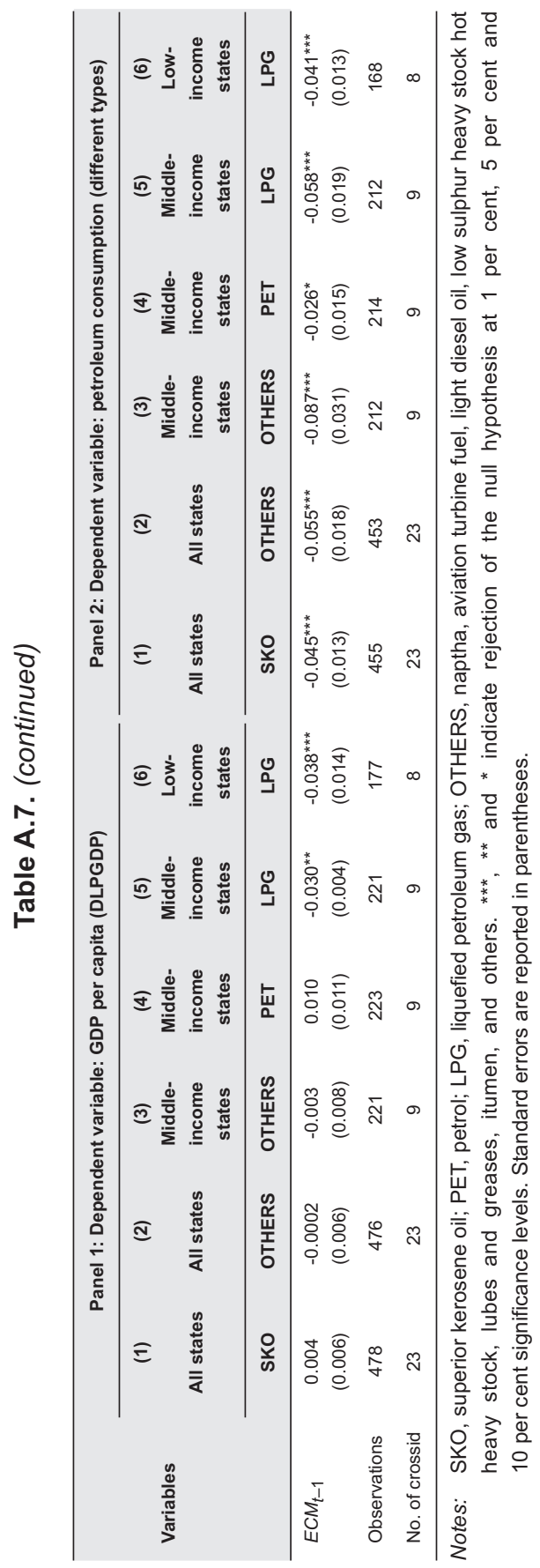




\section{Table A.8. Long-run models with disaggregate energy sources}

Using the feasible generalized least squares (FGLS) methodology, we estimate the long-run relationship between different types of petroleum consumption and economic growth that we found evidence of cointegration. Note that we found no evidence of cointegration for the group of high-income states.

\begin{tabular}{|c|c|c|c|c|}
\hline & $\begin{array}{c}(1) \\
\text { SKO }\end{array}$ & $\begin{array}{c}(2) \\
\text { OTHERS }\end{array}$ & $\begin{array}{c}(3) \\
\text { PET }\end{array}$ & $\begin{array}{c}(4) \\
\text { LPG }\end{array}$ \\
\hline \multicolumn{5}{|l|}{$P E C=f(P G D P)$} \\
\hline All states & $\begin{array}{c}0.051^{*} \\
(0.026)\end{array}$ & $\begin{array}{c}0.944^{*} \\
(0.056)\end{array}$ & & \\
\hline Observations & 641 & 640 & & \\
\hline Number of crossid & 23 & 23 & & \\
\hline Middle-income states & & $\begin{array}{l}0.756^{* * *} \\
(0.100)\end{array}$ & $\begin{array}{l}1.259^{\star \star \star} \\
(0.066)\end{array}$ & $\begin{array}{l}1.820^{* * *} \\
(0.072)\end{array}$ \\
\hline Observations & & 250 & 251 & 249 \\
\hline Number of crossid & & 9 & 9 & 9 \\
\hline Low-income states & & & & $\begin{array}{l}0.425^{\text {***}} \\
(0.033)\end{array}$ \\
\hline Observations & & & & 221 \\
\hline Number of crossid & & & & 8 \\
\hline \multicolumn{5}{|l|}{$P G D P=f(P E C)$} \\
\hline All states & $\begin{array}{c}0.114^{*} \\
(0.059)\end{array}$ & $\begin{array}{c}0.328^{*} \\
(0.019)\end{array}$ & & \\
\hline Observations & 641 & 640 & & \\
\hline Number of crossid & 23 & 23 & & \\
\hline Middle-income states & & $\begin{array}{l}0.247^{* * *} \\
(0.033)\end{array}$ & $\begin{array}{l}0.469^{* * *} \\
(0.025)\end{array}$ & $\begin{array}{l}0.395^{\star \star *} \\
(0.016)\end{array}$ \\
\hline Observations & & 250 & 251 & 249 \\
\hline Number of crossid & & 9 & 9 & 9 \\
\hline Low-income states & & & & $\begin{array}{l}0.425^{\star * *} \\
(0.033)\end{array}$ \\
\hline Observations & & & & 221 \\
\hline Number of crossid & & & & 8 \\
\hline
\end{tabular}

Notes: PEC, per capita energy consumption; PGDP, per capita gross domestic product. SKO, superior kerosene oil; PET, petrol; LPG, liquefied petroleum gas; OTHERS, naptha, aviation turbine fuel, light diesel oil, low sulphur heavy stock hot heavy stock, lubes and greases, itumen, and others. ${ }^{* *}$, ${ }^{* *}$ and * indicate rejection of the null hypothesis at 1 per cent, 5 per cent and 10 per cent significance levels. Standard errors are reported in parentheses. 


\section{REFERENCES}

Abbas, F., and N. Choudhury (2013). Electricity consumption-economic growth nexus: an aggregated and disaggregated causality analysis in India and Pakistan. Journal of Policy Modeling, vol. 35 , No. 4 , pp. 538-553.

Ahmad, A., and others (2016). Carbon emissions, energy consumption and economic growth: an aggregate and disaggregate analysis of the Indian economy. Energy Policy, No. 96, pp. 131-143.

Akarca, A.T., and T.V. Long (1980). On the relationship between energy and GNP: a re-examination. The Journal of Energy Development, vol. 5, No. 2, pp. 326-331.

Akhmat, G., and K. Zaman (2013). Nuclear energy consumption, commercial energy consumption and economic growth in South Asia: bootstrap panel causality test. Renewable and Sustainable Energy Reviews, vol. 25, pp. 552-558.

Apergis, N., and J.E. Payne (2009a). Energy consumption and economic growth: evidence from the Commonwealth of Independent States. Energy Economics, vol. 31, No. 5, pp. 641-647.

(2009b). Energy consumption and economic growth in Central America: evidence from a panel cointegration and error correction model. Energy Economics, vol. 31, No. 2, pp. 211-216.

Asafu-Adjaye, J. (2000). The relationship between energy consumption, energy prices and economic growth: time series evidence from Asian developing countries. Energy Economics, vol. 22, No. 6, pp. 615-625.

Bayer, Christian, and Christoph Hanck (2009). Combining non-cointegration tests. Research Memorandum 012. Maastricht University, Maastricht Research School of Economics of Technology and Organization (METEOR).

Bhattacharyya, S.C. (2015). Influence of India's transformation on residential energy demand. Applied Energy, vol. 143, pp. 228-237.

Bildirici, Melike E., and Tahsin Bakirtas (2014). The relationship among oil, natural gas and coal consumption and economic growth in BRICTS (Brazil, Russian, India, China, Turkey and South Africa) countries. Energy, vol. 65, pp. 134-144.

British Petroleum (2019). BP Statistical Review of World Energy 2019. Available at www.bp.com/content/ $\mathrm{dam} / \mathrm{bp} / \mathrm{business-sites/en/global/corporate/pdfs/energy-economics/statistical-review/bp-stats-}$ review-2019-full-report.pdf.

Cowan, W., and others (2014). The nexus of electricity consumption, economic growth and CO2 emissions in the BRICS countries. Energy Policy, vol. 66, pp. 359-368.

Di lorio, F., and S. Fachin (2007). Testing for breaks in cointegrated panels-with an application to the Feldstein-Horioka puzzle. Economics: The Open-Access, Open-Assessment E-Journal, vol. 1.

Dickey, D., and W. Fuller (1979). Distribution of the estimators for autoregressive time series with a unit root. Journal of the American Statistical Association, vol. 74, No. 377, pp. 427-431.

Dutta, M., and S. Mukherjee (2010). An outlook into energy consumption in large scale industries in India: the cases of steel, aluminium and cement. Energy Policy, vol. 38, No. 11, pp. 7286-7298.

Engle, Robert F., and C.W.J. Granger (1987). Co-integration and error correction: representation, estimation, and testing. Econometrica, vol. 55, No. 2 pp. 251-276. 
Fang, Z., and Thai-Ha Le (forthcoming). Cointegrating relationship and Granger causal analysis in energy economics - a practical guidance. In Handbook of Energy Finance: Theories, Practices and Simulations, S. Goutte and and N. Khuong, eds. World Scientific Publishing, Forthcoming in December 2019.

Fisher, Ronald Aylmer (1932). Statistical Methods for Research Workers, 4th ed. Edinburgh: Oliver \& Boyd.

Ghosh, S. (2002). Electricity consumption and economic growth in India. Energy Policy, vol. 30, No. 2, pp. 125-129.

Govindaraju, V.G.R. Chandran, and Chor Foon Tang (2013). The dynamic links between CO2 emissions, economic growth and coal consumption in China and India. Applied Energy, vol. 104, pp. 310-318.

Greene, W.H. (2008). Econometric Analysis, 6th ed. Upper Saddle River, New Jersey: Prentice Hall.

Im, K.S., M.H. Pesaran, and Y. Shin (2003). Testing for unit roots in heterogeneous panels. Journal of Econometrics, vol. 115, No. 1, pp. 53-74.

International Energy Agency (IEA) (2015). India Energy Outlook, World Energy Outlook Special Report. Paris: IEA Publications.

Johansen, S. (1988). Statistical analysis of cointegration vectors. Journal of Economic Dynamics and Control, vol. 12, No. 2-3, pp. 231-254.

Kao, C. (1999). Spurious regression and residual-based tests for cointegration in panel data. Journal of Econometrics, vol. 90, No. 1, pp. 1-44.

Kónya, L. (2006). Exports and growth: Granger causality analysis on OECD countries with a panel data approach. Economic Modelling, vol. 23, No. 6, pp. 978-982.

Kraft, J., and A. Kraft (1978). On the relationship between energy and GNP. The Journal of Energy and Development, vol. 3, No. 2, pp. 401-403.

Le, T.H. (2016). Dynamics between energy, output, openness and financial development in sub Saharan African countries. Applied Economics, vol. 48, No. 10, pp. 914-933.

Le, T.H., and C.P. Nguyen (2019). Is energy security a driver for economic growth? Evidence from a global sample. Energy Policy, vol. 129, pp. 436-451.

Le, T.H., and E. Quah (2018). Income level and the emissions, energy, and growth nexus: evidence from Asia and the Pacific. International Economics, vol. 156, pp. 193-205.

Lee, C.C., and C.P. Chang (2005). Structural breaks, energy consumption, and economic growth revisited: evidence from Taiwan. Energy Economics, vol. 27, No. 6, pp. 857-872.

Levin, A., C.F. Lin, and C.S.J. Chu (2002). Unit root tests in panel data: asymptotic and finite-sample properties. Journal of Econometrics, vol. 108, No. 1, pp. 1-24.

Maddala, G.S., and S. Wu (1999). A comparative study of unit root tests with panel data and a new simple test. Oxford Bulletin of Economics and Statistics, vol. 61, No. S1, pp. 631-652.

Mallick, H., M.K. Mahalik, and M. Sahoo. (2018). Is crude oil price detrimental to domestic private investment for an emerging economy? The role of public sector investment and financial sector development in an era of globalization. Energy Economics, vol. 69, pp. 307-324.

Nain, Z., W. Ahmad, and B. Kamaiah (2015). Economic growth, energy consumption and CO2 emissions in India: a disaggregated causal analysis. International Journal of Sustainable Energy, vol. 36, No. 8, pp. 807-824. 
Nain, M., S.S. Bharatam, and B. Kamaiah (2017). Electricity consumption and NSDP nexus in Indian states: a panel analysis with structural breaks. Economics Bulletin, vol. 37, No. 3, pp. 1581-1601.

Narayan, P.K., S. Narayan, and S. Popp (2010a) Does electricity consumption panel Granger cause GDP? A new global evidence. Applied Energy, vol. 87, No. 10, pp. 3294-3298.

(2010b). A note on the long-run elasticities from the energy consumption-GDP relationship. Applied Energy, vol. 87, No. 3, pp. 1054-1057.

Narayan, S. (2016). Predictability within the energy consumption-economic growth nexus: some evidence from income and regional groups. Economic Modelling, vol. 54, pp. 515-521.

Narayan, S., B.N. Rath, and P.K. Narayan (2012). Evidence of Wagner's law from Indian states. Economic Modelling, vol. 29, No. 5, pp. 1548-1557.

Naser, H. (2015). Analysing the long-run relationship among oil market, nuclear energy consumption, and economic growth: an evidence from emerging economies. Energy, vol. 89, pp. 421-434.

Nasreen, S., and S. Anwar (2014). Causal relationship between trade openness, economic growth and energy consumption: a panel data analysis of Asian countries. Energy Policy, No. 69, pp. 82-91.

Oh, W., and K. Lee (2004). Causal relationship between energy consumption and GDP revisited: the case of Korea 1970-1999. Energy Economics, vol. 26, No. 1, pp. 51-59.

Pao, H.-T., and C.-M. Tsai (2010). CO2 emissions, energy consumption and economic growth in BRIC countries. Energy Policy, vol. 38, No. 12, pp. 7850-7860.

Parikh, J., and K. Parikh (2011). India's energy needs and low carbon options. Energy, vol. 36, No. 6, pp. 3650-3658.

Parikh, J., and others (2009). CO2 emissions structure of Indian economy. Energy, vol. 34, No. 8, pp. 1024-1031.

Paul, S., and R.N. Bhattacharya (2004). Causality between energy consumption and economic growth in India: a note on conflicting results. Energy Economics, vol. 26, No. 6, pp. 977-983.

Pedroni, P. (1999). Critical values for cointegration tests in heterogeneous panels with multiple regressors. Oxford Bulletin of Economics and Statistics, vol. 61, No. S1, pp. 653-670.

(2004). Panel cointegration: asymptotic and finite sample properties of pooled time series with an application to the PPP hypothesis. Econometric Theory, vol. 20, No. 3, pp. 597-625.

Pesaran, M. (2004). General diagnostic tests for cross section dependence in panels. CESifo Working Paper Series, No. 1229; IZA Discussion Paper, No. 1240. Available at https://pdfs.semantics cholar.org/7f14/e40e9ff7e57a8db34178ba001be3cac0720b.pdf?_ga=2.101567751. 764281370.1564432569-282743693.1564432569.

Pesaran, M.H., A. Ullah, and T. Yamagata (2008). A bias-adjusted LM test of error cross-section independence. The Econometrics Journal, vol. 11, No. 1, pp.105-127.

Phillips, P., and P. Perron (1988). Testing for unit root in time series regression. Biometrica, vol. 5, No. 2, pp. 335-346.

Proops, J.L.R. (1984). Modelling the energy-output ratio. Energy Economics, vol. 6, No. 1, pp. 47-51.

Rafiq, S., and R.A. Salim (2009). Temporal causality between energy consumption and income in six Asian emerging countries. Applied Economics Quarterly, vol. 55, No. 4, pp. 335-350. 
Saxena, V., and P.C. Bhattacharya (2018). Inequalities in LPG and electricity consumption in India: the role of caste, tribe, and religion. Energy for Sustainable Development, vol. 42, No. C, pp. 44-53.

Sen, A., and A. Sen (2016). India's oil demand: on the verge of 'take off'? OIES Paper, WPM 65. Oxford Institute for Energy Studies, University of Oxford.

Shahbaz, M., and others (2016). The role of globalization on the recent evolution of energy demand in India: implications for sustainable development. Energy Economics, vol. 55, pp. 52-68.

Singh, R. (2018). Energy sufficiency aspirations of India and the role of renewable resources: scenarios for future. Renewable and Sustainable Energy Reviews, vol. 81, part 2, pp. 2783-2795.

Stern, D.I. (1993). Energy use and economic growth in the USA: a multivariate approach. Energy Economics, vol. 15, No. 2, pp.137-150.

Tiwari, A. (2011). Energy consumption, CO2 emissions and economic growth: evidence from India. Journal of International Business and Economy, vol. 12, No. 1, pp. 85-122.

Tiwari, A.K., M. Shahbaz, and Q.M.A. Hye (2013). The environmental Kuznet's curve and the role of coal consumption in India: cointegration and causality analysis in an open economy. Renewable and Sustainable Energy Reviews, vol. 18, pp. 519-527.

Toda, H.Y., and T. Yamamoto (1995). Statistical inference in vector autoregressions with possibly integrated processes. Journal of Econometrics, vol. 66, No. 1-2, pp. 225-250.

Verma, Nidhi (2018). India's oil imports in 2017 surged to a record 4.4 million bpd. Reuters, 16 January. Available at www.reuters.com/article/india-oil/indias-oil-imports-in-2017-surged-to-a-record-44-million-bpd-idINKBN1F5234.

Vidyarthi, H. (2013). Energy consumption, carbon emissions and economic growth in India. World Journal of Science, Technology and Sustainable Development, vol. 10, No. 4, pp. 278-287.

Wolde-Rufael, Y. (2010). Bounds test approach to cointegration and causality between nuclear energy consumption and economic growth in India. Energy Policy, vol. 38, No. 1, pp. 52-58.

Yang, H.Y. (2000). A note of the causal relationship between energy and GDP in Taiwan. Energy Economics, vol. 22, No. 3, pp. 309-317.

Yang, Z., and Y. Zhao (2014). Energy consumption, carbon emissions, and economic growth in India: evidence from directed acyclic graphs. Economic Modelling, vol. 38, pp. 533-540. 